\title{
Breaking Through the Zero Lower Bound
}




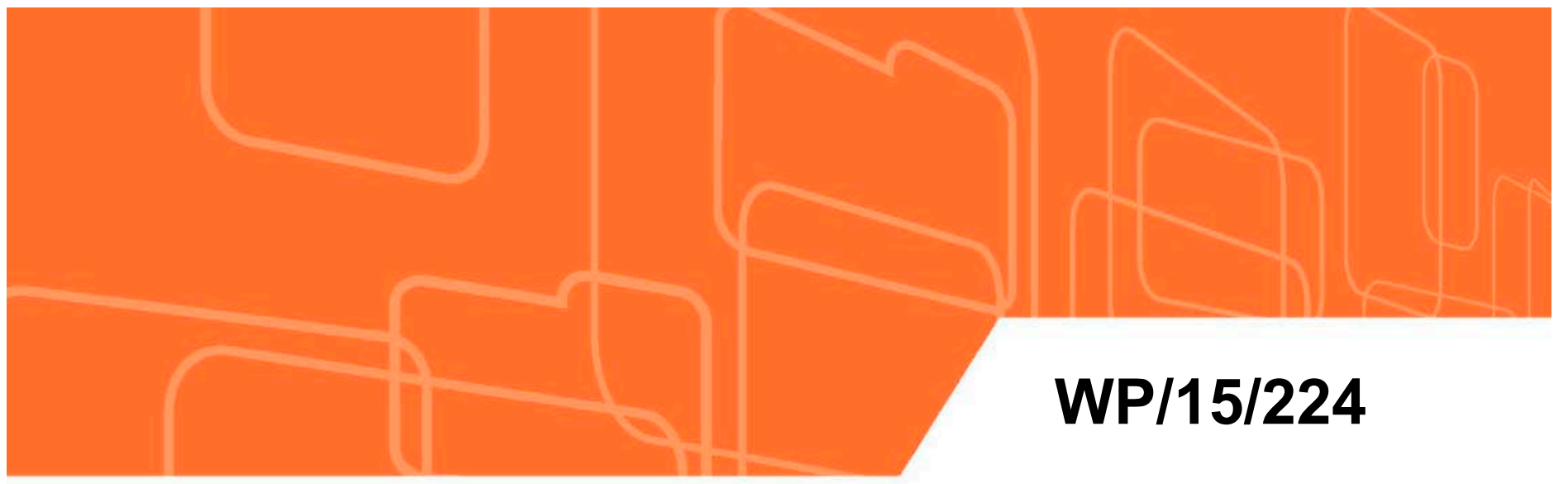

\section{IMF Working Paper}

\section{Breaking Through the Zero Lower Bound}

by Ruchir Agarwal and Miles Kimball

IMF Working Papers describe research in progress by the author(s) and are published to elicit comments and to encourage debate. The views expressed in IMF Working Papers are those of the author(s) and do not necessarily represent the views of the IMF, its Executive Board, or IMF management.

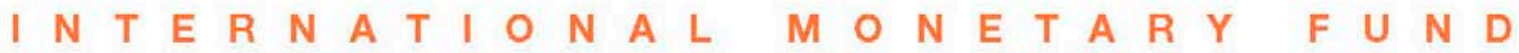




\title{
IMF Working Paper
}

Middle East and Central Asia Department

\section{Breaking Through the Zero Lower Bound}

Prepared by Ruchir Agarwal and Miles Kimball

Authorized for distribution by Annalisa Fedelino

October 2015

\section{IMF Working Papers describe research in progress by the author(s) and are published to elicit comments and to encourage debate. The views expressed in IMF Working Papers are those of the author(s) and do not necessarily represent the views of the IMF, its Executive Board, or IMF management.}

\begin{abstract}
There has been much discussion about eliminating the "zero lower bound" by eliminating paper currency. But such a radical and difficult approach as eliminating paper currency is not necessary. Much as during the Great Depression-when countries were able to revive their economies by going off the gold standard - all that is needed to empower monetary policy to cut interest rates as much as needed for economic stimulus now is to change from a paper standard to an electronic money standard, and to be willing to have paper currency go away from par. This paper develops the idea further and shows how such a mechanism can be implemented in a minimalist way by using a time-varying paper currency deposit fee between private banks and the central bank. This allows the central bank to create a crawling-peg exchange rate between paper currency and electronic money; the paper currency interest rate can be either lowered below zero or raised above zero. Such an ability to vary the paper currency interest rate along with other key interest rates, makes it possible to stimulate investment and net exports as much as needed to revive the economy, even when inflation, interest rates, and economic activity are quite low, as they are currently in many countries. The paper also examines different options available to the central bank to return to par when negative interest rates are no longer needed, and the associated implications for the financial sector and debt contracts. Finally, the paper discusses various legal, political, and economic challenges of putting in place such a framework and how policymakers could address them.
\end{abstract}

JEL Classification Numbers: E4, E5

Keywords: negative interest rates, electronic money, monetary policy

Authors’ E-Mail Addresses: ragarwal@imf.org, nkimball@umich.edu 
Abstract

I. Introduction

II. Using Electronic Money to Act Against Paper Currency Storage.

A. Overview

B. Electronic Money As Unit of Account With A Time-Varying Deposit Fee for Paper Currency.

C. The Paper Currency Interest Rate

D. Returning To Par When Negative Interest Rates Are No Longer Needed

E. Why Is There No Arbitrage?

F. Pass-Through of Negative Interest Rates and of the Exchange Rate.

III. The Impact of Negative Interest Rates and Paper Currency Off Par on the Financial Sector.

A. Impact on Banks

B. Possible Paths for the Spread Between the Paper Currency Interest Rate and the Target Rate.....

C. Impact on Debt Contracts

IV. Is Breaking Through the Zero Lower Bound Desirable?

A. Costs and Benefits of Paper Currency Away from Par............................................... 18

B. Costs and Benefits of Negative Interest Rates......................................................... $\underline{20}$

V. What Does it Take to Break Through the Zero Lower Bound?

A. What If the Government Has Trouble Establishing Electronic Money as the Unit of Account?.

B. Avoiding Paperization by Avoiding Prolonged Use of Negative Interest Rates Without Lowering the Paper Currency Interest Rate Below Zero.

C. Can Things Other than Paper Currency Create a Zero Lower Bound? $\underline{28}$

D. What If Paper Currency Is Still Legal Tender? .$\underline{28}$

E. The Role of Transactions Share in Bolstering Electronic Money as the Unit of Account

VI. Misconceptions About Eliminating the Zero Lower Bound .......................................... $\underline{31}$

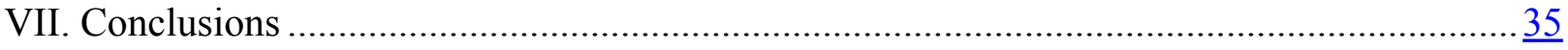

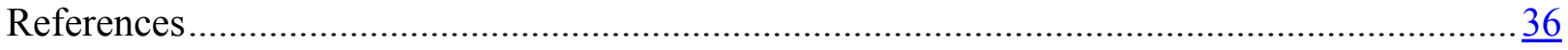

Appendix I. Potential Steps in the Transition from Paper Standard to Electronic Money ........... $\underline{38}$ 


\section{INTRODUCTION}

The zero lower bound arises when a government issues pieces of paper (or coins) guaranteeing a zero nominal interest rate, over all horizons, that can be obtained in unlimited quantities in exchange for money in the bank. This acts as an interest rate floor, making people unwilling to lend at significantly lower rates. The zero lower bound has proved to be a serious obstacle for monetary policy, as shown by the recent efforts of central banks to stimulate economic growth in the wake of the Global Financial Crisis. In this paper, we discuss how a transitional electronic money system - with paper currency still in use, but electronic money as the unit of account - can allow policymakers to break through the zero lower bound. ${ }^{1}$

We show here how the combination of (a) using electronic money as the unit of account and (b) a time-varying paper currency deposit fee can be used to eliminate the option to circumvent the negative rates by withdrawing, storing and, later, redepositing paper currency. The key idea is that a negative interest rate can be accompanied by a time-varying deposit fee that ensures the value of paper money and the value of funds in electronic accounts will move in tandem. Such a deposit fee only needs to be imposed at the central bank's cash window ${ }^{2}$ - the facility through which the central bank and commercial banks interact to bring cash in to and out of circulation - and not on households, firms, or banks. Levying the paper currency deposit fee on net deposits of paper currency allows the central bank to create an exchange rate at the cash window between electronic currency and paper currency, so that in a negative interest environment, the value of paper currency can be caused to depreciate over time relative to electronic money. The objective is a policy at minimum distance from the current monetary system consistent with eliminating the zero lower bound. In particular, such a policy requires no extra regulations or quantity constraints. Instead, its impact on the economy works entirely through the price system.

This paper builds on a long line of work on how to get a non-zero nominal rate of return on paper currency. First, Silvio Gesell in 1906 proposed the idea of stamped currency which allows the government to effectively tax paper currency, thereby discouraging massive paper currency storage when interest rates go below zero. Marvin Goodfriend (2000) has advocated a modern version of stamped paper currency - with electronic strips on the bills. Despite wide awareness among economists of the idea of stamped currency at least since John

\footnotetext{
${ }^{1}$ The central bank or another arm of the government could also create an interest rate floor by insisting that some other government borrowing rate go no lower than zero with similar guarantees. For example, the deposit rate for postal savings in Japan, or the interest rate on reserves, wherever reserve accounts exist, could create such an interest rate floor. However, in practice, the government guarantee of a zero paper currency interest rate has been most resistant to change, and therefore has garnered research interest.

${ }^{2}$ In the United States, for example, banks get cash from Federal Reserve (Fed) Banks. According to the Federal Reserve, "most medium- and large-sized banks maintain reserve accounts at one of the 12 regional Federal Reserve Banks, and they pay for the cash they get from the Fed by having those accounts debited. Some smaller banks maintain their required reserves at larger 'correspondent' banks. The smaller banks get cash through the correspondent banks, which charge a fee for the service. The larger banks get currency from the Fed and pass it on to the smaller banks." Source: http://www.newyorkfed.org/aboutthefed/fedpoint/fed01.html.
} 
Maynard Keynes discussed Gesell's idea in his The General Theory of Employment, Interest and Money in 1936, it has never been implemented at a national level. We suspect this is due in important measure to the political difficulties occasioned, because it requires an inconvenient and highly salient bureaucratic machinery to implement it and because it looks like a tax, to which a large section of the population is therefore averse.

\section{Figure 1. The Paper Currency Deposit Fee at the Cash Window of the Central Bank 1/}

\section{How a deposit fee on paper currency would work}

1. When there is a negative interest rate on electronic money (reserve accounts), there would be an increasing discount on withdrawals of cash. With the discount the value of paper money and money held electronically Nould change in tandem.
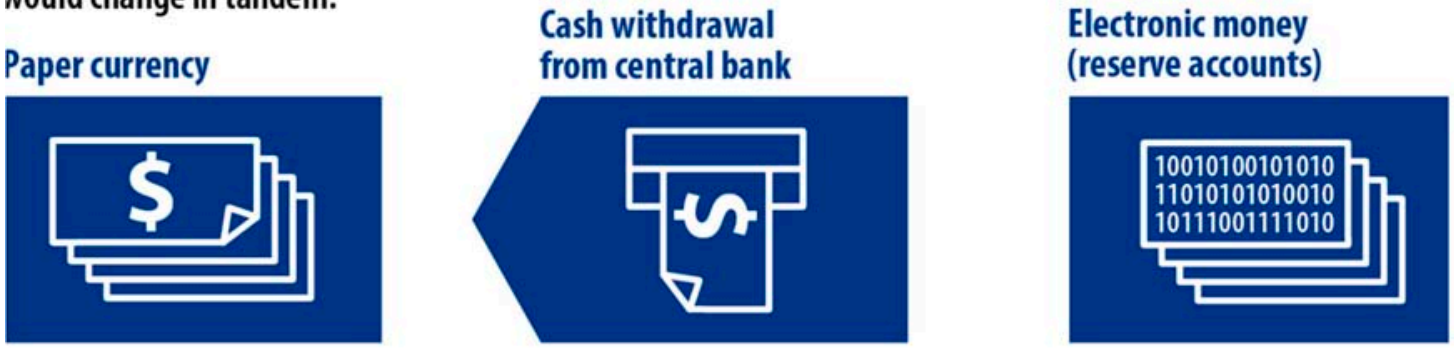

2. When there is a negative interest rate on electronic money, there would also be a fee when depositing paper currency. This would prevent the circumvention of negative rates by the withdrawal of paper currency.

Paper currency

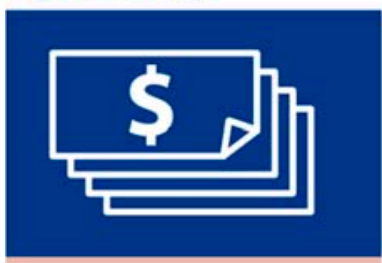

The effective value of paper money is reduced as there is an increasing deposit fee.

\section{Deposit money at the} central bank

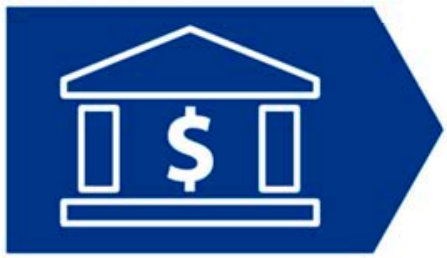

Central bank asks for deposit fee. Increases daily according to the negative rate on electronic money.

\section{Electronic money (reserve accounts)}

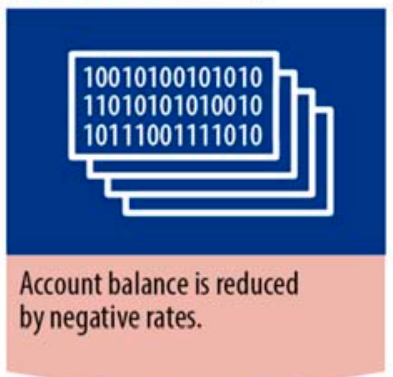

Source: The graphic above was graciously provided by Finanz und Wirtschaft through the good offices of Alexander Trentin. It is based on an interview with Miles Kimball. Used by permission.

$1 /$ Note that levying the fee on net deposits implies that less than the par amount is deducted from a bank's reserve account when paper currency is withdrawn.

An alternate line of thinking to deal with the zero lower bound - starting with Robert Eisler (1932) - focuses on a depreciation mechanism for paper currency. Such ideas involve distinguishing between paper currency and electronic money (or bank money as Robert Eisler called it), with the electronic money being the unit of account: the "real thing." This distinction makes it possible to engineer depreciation of paper currency relative to the electronic currency, thereby discouraging massive paper currency storage when faced with negative interest rates. In modern form, Buiter (2004, 2007, 2009a, 2009b, and 2009c) laid out these three approaches of stamped currency, abolition of paper currency, and an exchange rate between paper currency and electronic money. 
One way to classify the history of thought on ways to get a non-zero nominal rate of return on paper currency is to distinguish between two components of the nominal rate of return on paper currency: dividend yield and capital gains rate. The nominal rate of return on paper currency can be written as:

$$
\begin{array}{r}
\text { Rate of Return }=\left(\frac{\text { Dividend }_{t+1}}{P_{t}}\right)+\left(\frac{P_{t+1}}{P_{t}}\right)-1 \\
=\text { Dividend Yield }+ \text { Capital Gains Rate } \\
=\text { Dividend Yield }+ \text { Appreciation Rate }
\end{array}
$$

Proposals in the spirit of Gesell (1906) and Goodfriend (2000) target the dividend yield to generate a negative rate of return on paper currency; proposals in the spirit of Eisler (1932), Buiter (2004, 2007, 2009a, 2009b, and 2009c) and this paper target the capital gains rate. One benefit of mechanisms that target the capital gains rate (or equivalently, the appreciation rate) is that they work indirectly in their effects on ordinary transactions by households. This increases the political feasibility of such proposals relative to those targeting dividend yields. (In either case, for the rest of paper we use the following terminology: we call the rate of return on paper currency the 'paper currency interest rate' when tightly controlled to be a safe nominal daily or weekly rate.)

Some academics such as Ken Rogoff (2014) and journalists such as Matthew Yglesias (2011) and Izabella Kaminska $(2009,2013,2014)$ have gone further and suggested that a complete abolition of paper currency would eliminate the option of massive paper currency storage, eliminating the zero lower bound. Rogoff's proposal involves several stages with the first steps involving removing large-denomination currencies (e.g., \$100 and above) from circulation. While the complete abolition of paper currency would indeed clear the way for deep negative interest rates whenever deep negative rates were called for, such proposals remain difficult to implement since they involve a drastic change in the way people transact. Moreover, many economic agents have a demand for paper currency for the sake of privacy, ensuring that its total abolition would be quite controversial. Therefore, even if advocates of a cashless economy are ultimately successful, a transition to a cashless monetary system could easily take decades. For those who see a cashless economy as a likely eventual outcome of monetary evolution, our proposal can be seen as a transitional system. The key difference is that, unlike the cashless economy, any central bank can implement, if necessary, a time-varying paper currency deposit fee at its cash window within a matter of weeks. Even for central banks that currently do not need negative interest rates, the transitional system we propose will be much easier to put in place in time to deal with the next deep recession than a cashless economy would be.

Given their different time horizons, we see breaking through the zero lower bound with a time-varying paper currency deposit fee at the cash window of the central bank and heading toward a cashless economy as complementary policies. In particular, articulating a long-run goal of heading toward a cashless economy may be helpful in navigating the politics of moving paper currency from a central to a peripheral role in the transitional system we are proposing here. 
The zero lower bound is a serious obstacle for monetary policy. With Denmark, Sweden, Switzerland, Sweden, and the Eurozone's experience in $2014-15,{ }^{3}$ we have already crossed the rubicon of implementing negative rates and have begun to get a better sense of the size and shape of many of the political issues raised by negative interest rates themselves. The mechanism described in this paper is a way to make deeper negative interest rates possible, adding to the monetary policy toolkit in a way that not only (a) enables economic stabilization $^{4}$ without the side effects of other methods of stimulus, but also (b) makes it possible to lower the long-run inflation target to zero without sacrificing effective macroeconomic stabilization through interest rate policy. Thus, building on a long line of thinking about breaking through the zero lower bound, this paper shows how subordinating paper currency to electronic money can end recessions and end inflation.

The rest of the paper is organized as follows. Section II discusses how electronic money can be used to act against paper currency storage. Section III discusses the potential impact of negative interest rates on the financial sector and financial contracts. Section IV addresses whether it is desirable to break through the zero lower bound, discussing the costs and benefits of being away from par, and of having negative interest rates. Section V includes sections related to challenges in practical implementation of breaking through the zero lower bound, while Section VI discusses misconceptions about eliminating the zero lower bound. Lastly, Section VII concludes with some final thoughts.

\section{Using Electronic Money to Act Against Paper Currency Storage}

\section{A. Overview}

Short of stamped currency or the abolition of paper currency, the government can discourage paper currency storage in essentially three ways, corresponding to the three steps needed to earn an interest rate of zero minus storage costs from paper currency: it can attack withdrawal of paper currency, storage of paper currency, or redeposit of paper currency.

To attack withdrawal of paper currency, the government could implement a restriction or fee on paper currency withdrawals from bank accounts (or in the extreme, end the printing of new paper currency, forcing people to make do with the existing stock). There are several disadvantages to this approach. First, it prevents withdrawal for spending as well as withdrawal for storage. Second, the ability to withdraw paper currency has great option value for people, which restrictions or fees on withdrawal would damage. Third, whether a withdrawal fee of a given size is adequate to prevent massive paper currency storage depends crucially not only on how negative interest rates are, but for how long they will be negative,

\footnotetext{
${ }^{3}$ These countries have implemented negative rates under different exchange rate regimes. Denmark, for example, has a fixed exchange rate regime, while Sweden operates under an inflation targeting framework. Our paper focuses on the case in which the central bank retains an independent monetary policy.

${ }^{4}$ The overall potential of stabilization through interest rate policy is unclear. However, what evidence exists for a "Great Moderation" in the period after the end of the "Great Inflation" and before any given central bank was seriously hampered by the zero lower bound suggests a lower bound for the value of unhampered interest rate policy.
} 
which is difficult to know in advance. Fourth, with quantity restrictions on withdrawals - or fees high enough that the corner solution of withdrawing zero is often attractive - the effective price of paper currency would likely follow a jagged diffusion process as information and expectations evolved. Finally, people would still have an incentive to hoard the paper currency already in their possession, and to withdraw as much as possible in advance of the imposition of a withdrawal fee. This makes it more difficult to openly discuss and debate the imposition of a withdrawal fee.

To attack storage, the government could attempt to make storage of paper currency costly by taxing or prohibiting storage. There is a limit to how effective this can be, since storage of paper currency can be done in low-tech ways by anyone. Moreover, criminals already have experience in secret storage of paper currency. Thus, while storage of paper currency can be driven underground, it is hard to fully prevent. The ease of small-scale storage of paper currency by households, in particular, could lead to fewer funds left in demand deposits or savings accounts and hence to significant disintermediation even if commercial-scale paper currency storage could be successfully blocked. ${ }^{5}$

The third option for the government is to implement a temporary fee on deposit or re-deposit of paper currency at the cash window of the central bank. Such a fee, when implemented in a time-varying manner on net deposits, creates an effective exchange rate between paper currency and electronic money, and allows the government to avoid the disadvantages of the first two options discussed above. The next section describes this mechanism in further detail.

\section{B. Electronic Money As Unit of Account With A Time-Varying Deposit Fee for Paper Currency}

One of the great advantages of the time-varying deposit fee is that its implementation only involves modifying what happens at the cash window of the central bank. When private banks come to deposit paper currency at the cash window, a fee is levied. No new regulations are needed on what the private banks do in interaction with their customers (though it might be necessary to remove any regulations that force them to treat cash on a par with electronic payment).

Once the time-varying deposit fee is in place, one can predict that to avoid the deposit fee banks would offer paper currency to customers at a discount. Hence, if banks are still making deposits with the central bank at all, the deposit fee would establish an exchange rate between paper currency and electronic money. In effect, ignoring transactions costs, the rate at which paper currency trades (or "the exchange rate") will be equal to (1-deposit fee).

\footnotetext{
${ }^{5}$ One difficulty with inhibiting small-scale paper currency storage by force of law is the difficulty in drawing the line between what a household or firm can argue are "normal" paper currency holdings and what are holdings resulting from the desire to escape negative interest rates.
} 
Ideally, to maintain control over this exchange rate even when banks are not making deposits, the central bank can make it a two-way exchange rate by allowing withdrawals of paper currency at a discount as well. This can be achieved by charging the deposit fee on net deposits. ${ }^{6}$

While this exchange rate would hold throughout the financial system, it need not hold at retail shops that deal regularly with both cash and credit or debit cards. As it is, in the United States, for example, many retail shops accept at par credit card payments that are worth as little as 96 cents or 97 cents on the dollar to them after credit card fees, even in states where treating cash payments and credit or debit card payments differently is fully legal. This holds true across a range of retailers that face quite different costs of handling paper currency. And other payments options with different net values are often accepted at par relatively to each other. The difference in fees between different types of credit cards can be more than 100 basis points without inducing a departure from taking each kind of payment at face value. The reasons for this are not yet fully understood, but presumably they include some benefit to treating payments of different kinds at face value even when the amount the retail shop gets is actually different. Indeed, the perceived value to accepting different types of payment all at face value seems big enough that shops often decide to refuse certain modes of payment entirely rather than impose surcharges for that mode (or giving discounts for other modes).

Considering the case of businesses that perceive a low cost of handling cash, up to a deposit fee of several percent, the gap between what they get in the end from cash as opposed to credit or debit card payments would actually shrink if paper currency were below par when deposited in the bank, making it even more likely that all types of payments would be treated on a par at retail than now. The clearest example is this: if one paper dollar is worth 97 cents at the bank and a credit card payment with a face value of one dollar is worth 97 cents to a retailer after the credit card fee, why should the retailer treat them differently? We return to this issue of pass-through of the exchange rate to retail transactions below. ${ }^{7}$

\footnotetext{
${ }^{6}$ In addition to establishing a clearly defined crawling peg for the exchange rate, another advantage to levying the deposit fee on net deposits is that it avoids the undesirable side effect of causing banks to reorganize physical cash flows to net out cash inflows and outflows among themselves before interacting with the central bank's cash window.

${ }^{7}$ To restate this idea more technically, studying retailer behavior in accepting a variety of different payment methods that have different costs for retailers can help identify the parameters that would govern when and where an exchange rate between paper currency and electronic money is partly or wholly passed through at retail in the form of a surcharge for paying cash. This is an important and urgent area for research. Such research needs to study the cost of handling cash by different businesses as well as the fees actually paid to, and restrictions contractually imposed by credit and debit card companies (which for large retailers are often individually negotiated with the credit and debit card companies). What matters most for negative interest rate policy is the outer limits of how different the net amount earned from $\$ 100$ face value can be before a retailer adds a surcharge to a given means of payment, and in what situations the retailer discontinues accepting a particular mode of payment.
} 


\section{The Paper Currency Interest Rate}

In the system we are proposing, it is the rate of change in the deposit fee that does the real work. The deposit fee must grow during the period the target interest rate is negative. On the other hand, it can be allowed to shrink when the interest rate is positive.

Since electronic money provides the unit of account, "nominal" means relative to an electronic dollar, euro, pound, or yen, and not relative to a paper dollar, euro, pound, or yen. Let $X$ denote the number of electronic dollars per paper dollar. Then the paper currency interest rate in this system is given by

$$
\text { Paper Currency Interest Rate }=\left(\frac{d X}{d t}\right) \frac{1}{X}
$$

Suppose at every meeting of the monetary policy committee, in addition to the target rate, interest rate on reserves, and lending rate, a fourth interest rate is chosen: the paper currency interest rate (PCIR). Then, starting at par plus keeping track of $(\mathrm{dX} / \mathrm{dt}) / \mathrm{X}=\mathrm{PCIR}$ mechanically determines $X$. Thus, at the inception of an electronic money system (that starts at par), the principles of compound interest with some combination of positive and negative interest rates determine what the exchange rate between paper currency and electronic money must be. Note that there are no extra degrees of freedom: the choice of the paper currency interest rate forces the choice of the exchange rate and of the paper currency deposit fee that creates that exchange rate. Maintaining flexibility for adjusting the paper currency interest rate along with other interest rates precludes making any commitments about the exchange rate independent of commitments about the paper currency interest rate.

Figure 2. Illustration of the Paper Currency Interest Rate Over Time

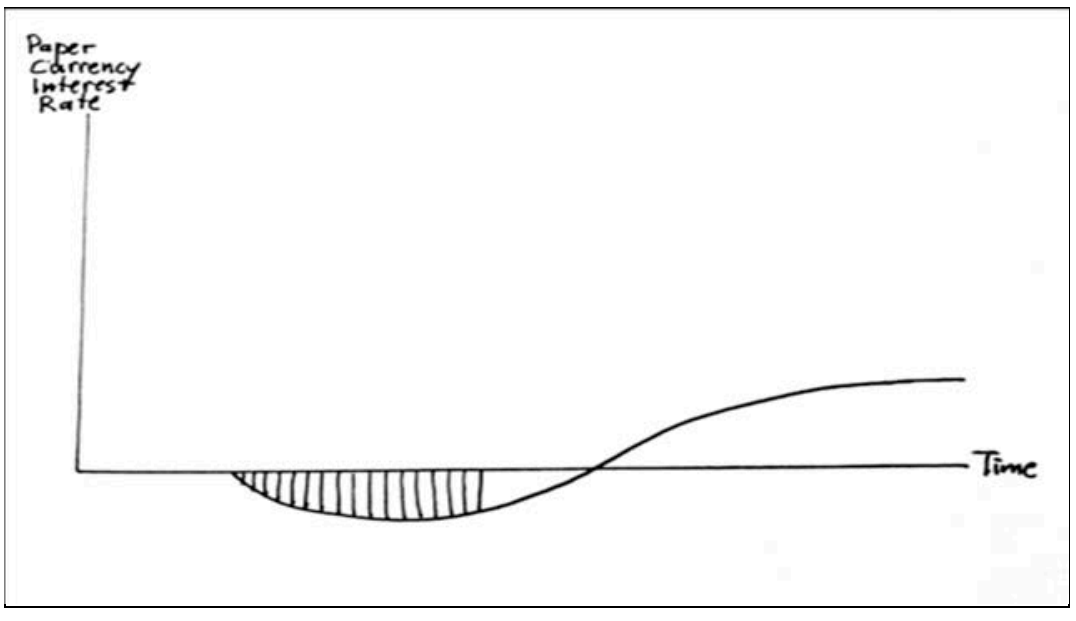




\section{Returning To Par When Negative Interest Rates Are No Longer Needed}

If (given economic recovery) the average nominal rate tracked by the PCIR over time is positive, the exchange rate can return to par. However, the decision on whether to return to par, and how, is a key policy choice of the central bank. Here, we consider four options available to the central bank for the time path of the effective interest rate on paper currency (PCIR) and the corresponding time path of the exchange rate.

Swift Return to Par: A swift return to par is a serious mistake, since it creates a lower bound further above zero than the intended target rate. As discussed above, the rate of appreciation of paper currency can be seen as the paper currency interest rate when electronic money is treated as the numeraire. When the exchange rate is substantially below par after a period of negative interest rates, a swift return to par would imply a high paper currency interest rate, which lenders would prefer to other interest rates during that period of time.

This problem cannot be escaped by going back to par suddenly, since any anticipation of such a move would give a very strong motive for paper currency storage in order to benefit from the capital gains on paper currency at that moment of sudden return to par from below par.

Because of this problem, in all of the other options, we envision the central bank committing to always keep the paper currency interest rate at most a small spread above the target interest rate and the interest rate on reserves - a spread smaller than the physical cost of storing paper currency. (From here on, we will assume that the interest rate on reserves is kept very close to the target rate.) This and the commitment to the exchange rate between paper currency and electronic money one day ahead are the only commitments necessary to make a negative interest rate policy work smoothly - other than the familiar commitment not to over-stimulate the economy that is important even when the zero lower bound is not an issue.

Gradual Return to Par: The second option is to keep the paper currency interest rate equal to the target rate (plus or minus a small spread) until parity is reached, and then setting the PCIR equal to zero. This rule implies a more moderate positive level of the PCIR during the return toward par than the first option discussed above. The "gradual return to par" option returns the exchange rate to par as fast as is consistent with keeping the zero lower bound non-binding at all times. The furthest distance below par, and the amount of time needed to return to par, can be reduced by keeping the paper currency interest rate slightly above the target rate (less than the perhaps 50 basis point physical cost of paper currency storage), but as discussed below, this direction of the spread may have adverse consequences for financial firms.

Having a small spread between the paper currency interest rate and the target rate during the time paper currency is away from par implies low shoe-leather costs. In this context, the shoe leather cost of holding paper currency is associated with the spread between the deposit rate and the paper currency interest rate--not with inflation. With the ability to have paper currency go away from par, paper currency is not favored by having a zero interest rate when other interest rates are negative, but paper currency is not disfavored: paper currency can be given an interest rate very similar to other prevailing short-term safe rates. 
Friedman Rule: The Friedman rule for paper currency is to make sure that shoe-leather costs remain zero at all times. Under this rule the paper currency rate always equals the target rate (or the deposit rate). This implies a time path for interest rates similar to the "gradual return to par" option while paper currency is below par. However, if the long-run average nominal interest rate is positive, the Friedman rule will eventually cause paper currency to go above par. Note that the Friedman rule can be implemented regardless of the rate of inflation in the electronic unit of account. Steady-state deflation relative to paper currency is achieved by having paper currency go further and further above par in steady state. The fact that the Friedman rule in this context is consistent with a zero inflation rate in the unit of account makes this implementation of the Friedman rule more appealing than an implementation that required deflation in the unit of account.

Seignorage without Inflation (Never Return to Par): The fourth option is to constantly depreciate paper currency to earn additional seignorage while maintaining low or zero inflation in the unit of account. This option can be thought of as an optimal tax problem from the government's perspective. The spread between the paper currency interest rate and other safe short-term rates can be considered the tax rate on paper currency. This is no longer an "inflation tax" because it is decoupled from the rate of inflation on the unit of account. It is simply a paper currency tax. ${ }^{8}$ Although the relationship between the paper currency interest rate and the target rate matters for this optimal tax problem, in this option the paper currency interest rate may be so low that avoiding a binding lower bound on other interest rates does not require any adjustment in the PCIR over time.

Figure 2 plots the four different options and their implications for the log exchange rate for paper currency in terms of electronic money $(\ln (\mathrm{X}))$. In the "swift return to par" case it is assumed for the sake of illustration that once negative interest rates are no longer needed the central bank chooses the PCIR with the aim of returning to par within four quarters. Consequently, $\ln (\mathrm{X})$ remains below par only for a short period of time. By contrast, in the "gradual return to par" case it is assumed that the central bank sets the PCIR equal to the target rate (plus or minus a small constant spread) except when that would take paper currency above par. Therefore, the return to par takes longer in this case compared to the first case. In the Friedman rule case, since the PCIR is set equal to the target rate at all times (plus or minus a small constant spread), $\ln (\mathrm{X})$ continues to rise even after parity is reached. Finally, in the "seignorage without inflation" case, it is assumed that the central bank sets a constant PCIR equal to -4 percent. Here the value of paper money relative to electronic money continues to fall in the steady state without creating inflation, since the unit of account is electronic money, and other interest rates are raised enough to avoid overheating the economy.

\footnotetext{
${ }^{8}$ There is likely to be some limit on how high the paper currency tax can be without people switching transactions they want to keep private to foreign paper currency. But this limit is likely to be of the same order of magnitude as how high nations in the past have been able to have inflation get before people switched to the use of foreign currency in transactions.
} 


\section{Figure 3. Options to Return to Par When Negative Rates Are Not Needed}

Case 1: Swift Return to Par (Percent)

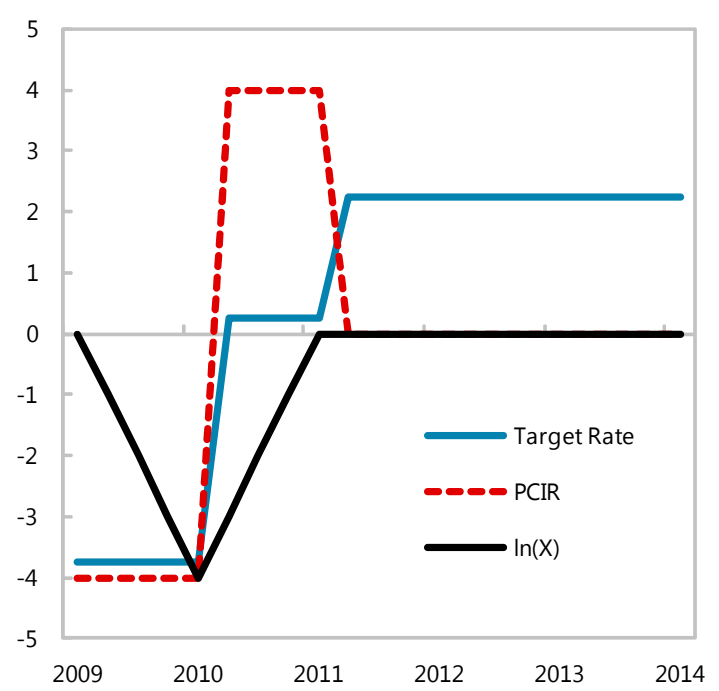

Case 3: Friedman Rule (Eventually Go Above Par) (Percent)

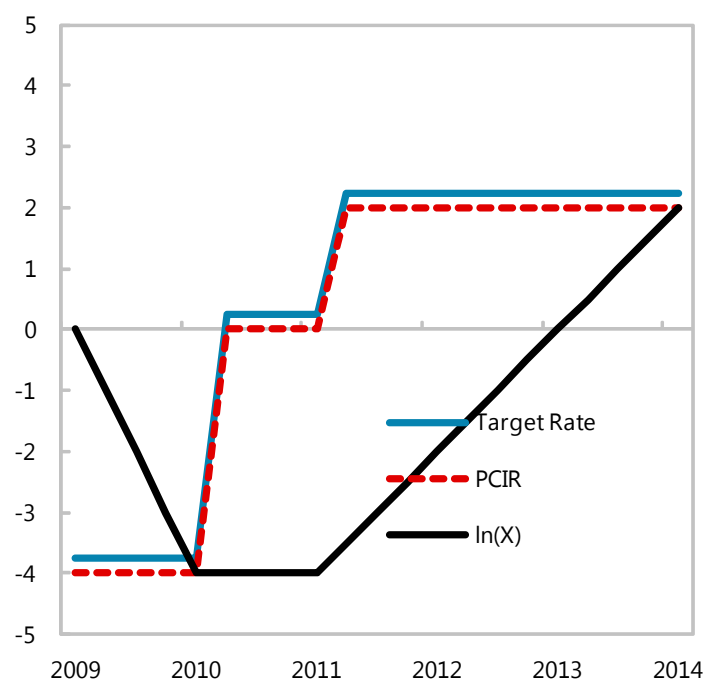

Case 2: Gradual Return to Par (Percent)

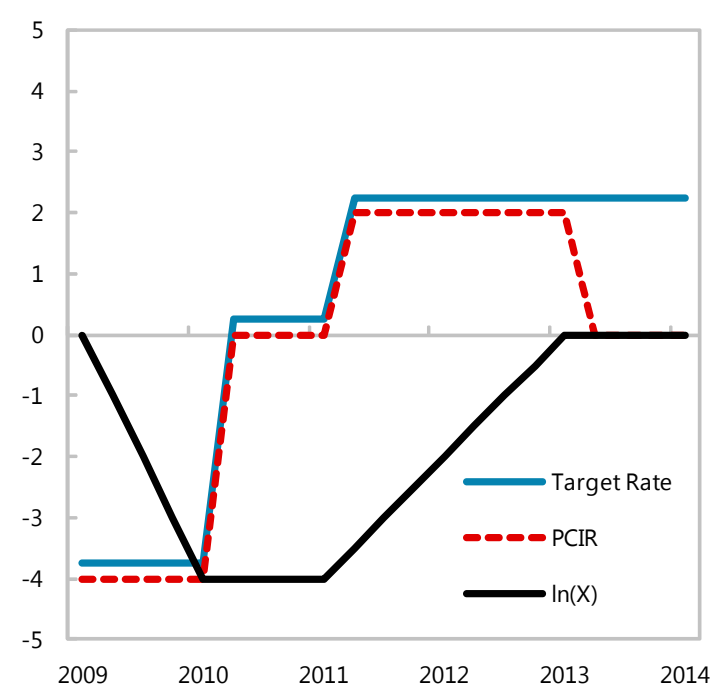

Case 4: Seignorage without Inflation (Never Return to Par) (Percent)

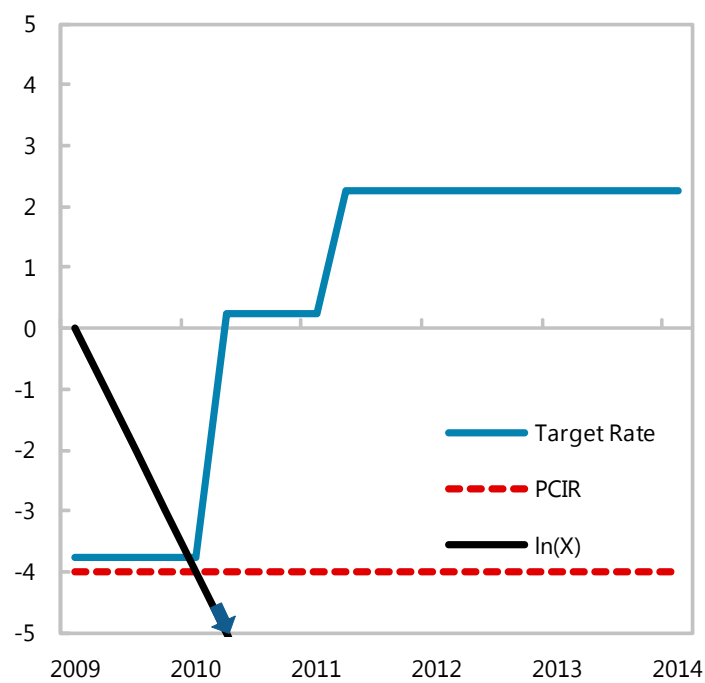

Note: Each option is presented as a possible alternative history for monetary policy in a country that was at the zero lower bound since end-2008. In several advanced countries the actual history has PCIR and $\ln (X)$ as flat lines at zero and the target rate as a flat line very close to zero throughout this period of time. 


\section{E. Why Is There No Arbitrage?}

Leaving aside storage costs of paper currency, the key condition for an absence of arbitrage between paper currency and other short-term rates is that the rate of return on paper currency - which we have been calling the paper currency interest rate-is essentially equal to other short-term interest rates. In the example in Figure 4 below, the key short term interest rates such as the interest rate on reserves, the repo rate and the short-term government bill rate are all treated as equal at -2 percent during 2009 and 2010, zero during 2011 and +2 percent thereafter.

Figure 4. Example of No Arbitrage

\begin{tabular}{|l|rrrrrrr}
\hline & 2009 & 2010 & 2011 & 2012 & 2013 & 2014 & 2015 \\
\hline electronic short-term rates & $-2 \%$ & $-2 \%$ & 0 & $2 \%$ & $2 \%$ & $2 \%$ & $2 \%$ \\
e- in a short-rate account on Jan. 1 & 100 & 98 & 96 & 96 & 98 & 100 & 102 \\
& & & & & & & \\
p-\$ face value in storage facility & 100 & 100 & 100 & 100 & 100 & 100 & 100 \\
paper currency interest rate (PCIR) & $-2 \%$ & $-2 \%$ & 0 & $2 \%$ & $2 \%$ & $0 \%$ & $0 \%$ \\
e- $\$$ per p-\$ & 1 & 0.98 & 0.96 & 0.96 & 0.98 & 1 & 1 \\
market value (in e-\$) of stored p-\$ & 100 & 98 & 96 & 96 & 98 & 100 & 100 \\
\hline
\end{tabular}

Again leaving aside storage costs, a paper currency interest rate above other short-term rates leaves open the possibility of an arbitrage of taking funds out of other short-term assets and storing paper currency instead. On the other hand, a paper currency interest rate below other short-term rates would make an arbitrage of shorting paper currency and putting the funds in other short-term assets attractive. However, governments jealously guard their monopolies in issuing paper currency. In Figure 4, because the paper currency interest rate is exactly equal to other short-term rates at all times from 2009 through 2014, there is no possible arbitrage. In 2015, the economy reverts to the familiar situation of other safe assets earning more than paper currency.

Another way to see the absence of an arbitrage opportunity is to look at what happens to the value of funds kept in an electronic short-rate account and the value of funds kept in paper currency. Rounding off a bit, $\$ 100$ deposited in January 1, 2009 into an electronic short rate account becomes on succeeding New Year's Days \$98, \$96, \$96, \$98, \$100, and $\$ 102$. The market value of paper currency put into storage on January 1, 2009 follows exactly the same track until 2014, when it stops at $\$ 100$, thus falling behind the value of funds in the electronic short-rate account. Moreover, choosing any starting date before January 1, 2014, equal values of money put into paper currency storage on the one hand and an electronic short-rate account on the other hand would match precisely in value until January 1, 2014, as long as the exchange rate was applied to convert the value of paper currency into the electronic-unit-of-account equivalent.

How can an exchange rate between paper currency and electronic money prevent any possible arbitrage without having to keep track of individual withdrawals and deposits of paper currency? The key is that the exchange rate is time-varying. Just as a sundial keeps track of how much time has elapsed by the difference between where the shadow was at the 
start of the interval and where it is at the end of the interval, during the time paper currency is off par and the PCIR is more or less equal to other short-term rates, the exchange rate at the central bank's cash window keeps track of how much cumulative interest has been earned in electronic accounts by how much it has changed over a given interval. This is just another way of saying that it is the depreciation and appreciation of the exchange rate that generates a paper currency interest rate equal to other short-term rates during that period, not the level of the exchange rate. (Equivalently, it is the rate of change in the paper currency deposit fee at the central bank's cash window-not its level—that is crucial.)

\section{F. Pass-Through of Negative Interest Rates and of the Exchange Rate}

Two of the most urgent research questions for understanding the effects of negative interest rate policies are to understand the extent of retail pass-through in different circumstances of negative interest rates and of an exchange rate between paper currency and electronic money at the central bank's cash window. Experience with negative interest rates in Switzerland, Sweden, Denmark and the eurozone indicates that as rates are cut below zero, negative interest rates are not immediately passed through to the small-scale bank accounts held by the typical household. Banks are likely to make a distinction in their strategy towards legacy customers and hot-money customers. Legacy customers with de facto loyalty to a given bank are a long-run source of profits; if their accounts are not too large, shielding them from modest negative interest rates may not cost that much and may be worth a lot in not alienating them. Hot-money customers have very little loyalty; the fact that they take advantage of a bank's above-market zero deposit rate today doesn't mean they will be there generating profits next year. So there is relatively little lost from making new customers who are more likely to be hot-money customers face negative deposit rates. In addition, customers who have very large accounts are expensive to subsidize with a zero deposit rate in a negative rate environment; they also tend to be more sophisticated and so less likely to desert a bank out of sheer emotional pique over negative rates. The upshot is that in an environment of modest negative interest rates, retail banks may shield most depositors from negative rates but subject the majority of dollars (or euros, yen, pounds, etc.) to the negative interest rates. This is exactly what a central bank concerned about both the political ramifications of negative rates and the transmission mechanism by which negative interest rates stimulate the economy would hope for. ${ }^{9}$

There is a general principle at work: many things that are a political problem for the central bank are also customer-relations problems for private firms. Hence the value to a central

\footnotetext{
${ }^{9}$ Preliminary evidence for the pass-through and demand for cash at negative interest rates comes from Denmark (Danmarks Nationalbank, Monetary Review ${ }^{\text {nd }}$ Quarter 2015, Article 2). Danmarks Nationalbank's rate of interest on certificates of deposit has been -0.75 percent since Feb 6, 2015. The interest rate on certificate of deposits was lowered into negative territory to defend the Danish fixed exchange rate policy. Denmark's monetary policy rates are set solely to maintain a fixed exchange rate of the krone against the euro. The Danmarks Nationalbank study finds that the negative interest rates have not weakened the pass-through from Danmarks Nationalbank's interest rates to money market rates. Moreover, consistent with the discussion above, they find that the negative interest rates have not been fully passed through to bank deposit and lending rates to households. However, large deposits from firms and institutional investors are extensively paying negative interest rates. Lastly, they find no evidence of any substantial change at the current level of interest rates in the way banknotes and coins (currency) in circulation are being used.
} 
bank of working indirectly: if the central bank can act in a way that works indirectly, through private firms, those private firms are likely to implement pass-through in a way that might blunt some of the political impacts the central bank is worried about without blunting too much of the effect on the economy. (A modest reduction in the strength of the transmission mechanism is not a serious problem here since with the zero lower bound broken, the magnitude of interest rate movements can be increased enough to compensate that loss in the impact of each basis point.)

Now consider pass-through of the exchange rate. Again, private firms have a concern about the effect on customer relations of a non-par exchange rate at retail that has a similar profile to the central bank's concern about the political implications of a non-par exchange rate at retail. Thus, at least for modest departures of the exchange rate from par, retailers concerned about customer relations are likely to shield customers from a non-par exchange rate at many shops, alleviating some of the political hit the central bank might otherwise have to absorb. The gradually increasing discount on cash goods purchased at par during at least the early part of the negative interest rate period means that the effective interest rate on cash goods purchased at shops that accept both cash and debit or credit cards will be higher than otherwise, which may blunt some of the extra demand for cash goods. But the primary transmission mechanisms for negative rates come from indirect effects through asset prices and exchange rates, and from purchases of investment goods, houses and durables that are usually purchased with electronic money (and might indeed be subject to a surcharge if purchased with cash). So any blunting of the transmission mechanism for cash goods should not be too problematic. (Note that this is a statement about the real world. Many models include only nondurable consumption goods, and have no investment or durables sector. Such models would give an unrealistic picture of the transmission mechanism for negative interest rates coupled with an appropriate exchange rate at the cash window of the central bank. Our perspective on the importance of durables and investment goods in models where monetary policy matters is informed by Barsky, House and Kimball, 2007.)

\section{THE IMPACT OF NEGATIVE INTEREST RATES AND Paper Currency Off Par on the Financial Sector}

\section{A. Impact on Banks}

The spread between other rates (target rate, interest on reserves, the discount rate) and the paper currency interest rate will matter to financial firms. With the introduction of electronic money this spread becomes a separate policy choice for the central bank. In either the gradual return to par option or the Friedman rule option, the paper currency interest rate moves in tandem with the other interest rates under the control of the central bank. Instead of moving three interest rates in tandem, with relatively constant spreads - target rate, interest rate on reserves and lending rate - the central bank moves four interest rates in tandem: target rate, interest rate on reserves, lending rate, and paper currency interest rate. The exception is that in the gradual return to par policy, staying at par is treated as having some value, so there may be times when the other interest rates are substantially above zero, but the paper currency interest rate is left at zero in order to maintain par once par has been restored. Banks make a living from spreads. Currently, negative nominal interest rates in Switzerland, Sweden, Denmark and the eurozone yield a very low (negative) spread of other rates over the 
paper currency rate of zero, which is likely to hurt financial firm profitability. An electronic money system, however, can avoid this side-effect of negative rates under current paper currency policies, since in an electronic money system the spread between the paper currency interest rate and other short-term rates is a policy variable under the control of the central bank. Because of the depreciation mechanism, people who actually face a negative deposit rate still have an incentive to put money in the commercial banks even if interest rates on deposits are negative. That reduces the negative impact on bank profits and bank balance sheets.

Of course, as discussed above, banks face customer relations problems that may lead them to shield some customers from negative rates; that could have some negative effect on bank profits and therefore on bank balance sheets. However, if the central bank is concerned about this negative impact on bank balance sheets, yet wants to encourage banks to shield small accounts from negative interest rates, it is easy to subsidize banks in their shielding of small accounts from negative rates by tying the ceiling on the amount of funds on which a bank can get an above-market zero interest rate in its reserve account to some evaluation of how well it is giving zero interest rates to households the central bank hopes will see zero interest rates and how well it is passing through negative rates to other depositors the central bank hopes will face negative interest rates. Thus, if they so choose, most central banks are likely to have within their own authority the ability to subsidize the provision of above-market rates for small accounts in a negative rate environment. Determining the narrow economic merits and demerits of such subsidies (including distributional concerns) would be a substantial task; but even if such subsidies would be inadvisable on those economic grounds alone, if such subsidies are necessary to make appropriate levels of negative rates politically acceptable, they may well be worth it on such political grounds.

\section{B. Possible Paths for the Spread Between the Paper Currency Interest Rate and the Target Rate}

Issues of pass-through at the research frontier greatly complicate assessing the effect of negative interest rate policies on banks. But it is useful to point out the implications of the options for whether and how to return to par discussed above for the spread between the paper currency interest rate and other short-term rates. This section's focus on bank profits motivates us to show the spread as the target rate minus the paper currency interest rate. 


\section{Figure 5. Spread Between Target Rate and PCIR}

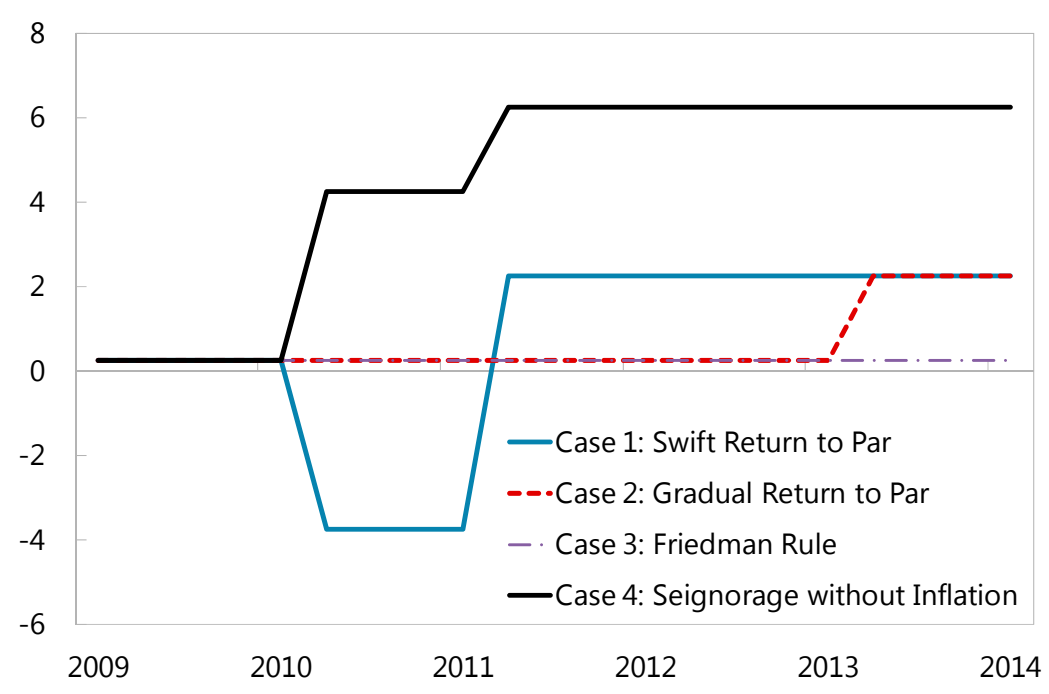

Figure 5 shows that under case 1 (swift return to par) the spread is not always positive, whereas under the other three cases the spread remains positive at all times. Such considerations may guide a central bank in their decision of how to choose the optimal path of the exchange rate between electronic money and paper money.

We see the "gradual return to par" option as the minimum distance from the current system - in part because the time at par looks very much like the current system. Within the "gradual return to par" option, it would be possible to set a fixed small spread between the paper currency interest rate and the target rate that would always be implemented except when paper currency is already at par and that spread would take it above bar by implying a positive PCIR. Such a fixed spread between the PCIR and the target rate has the advantage of breaking through the zero lower bound in a way that has a reassuring constancy to it. Thinking more narrowly of the central bank's communications problem, such a constant spread except when that spread would take paper currency above par has the advantage of being boring after some time under the new system. For example, a note toward the end of the announcement after a monetary policy committee meeting could say something like "As has been the case ever since the introduction of the electronic money system when the target rate is negative or in the aftermath of a negative rate period, the paper currency interest rate will be 10 basis points below the target rate." Given long-run constancy of the spread between the PCIR and the target rate (except when that spread would take paper currency above par) such a note at the end of the announcement might not even make it into key news articles about the monetary policy committee meeting at all.

\section{Impact on Debt Contracts}

Effect of Temporary Negative Rates. Like any decline in interest rates, negative interest rates raise the price of non-callable debt contracts over horizons over which interest rates definitely fall (as long as the current numeraire value of the payments is unchanged). 
However, negative interest rates may not always lead to an increase in the value of debt. If negative interest rates bring quicker economic recovery, they can raise medium-term real interest rates and therefore lower medium-term nominal bond prices. In addition, there are other mechanisms by which negative interest rates may affect debt contracts. For example, if elimination of the zero lower bound leads to a reduction in the long-run inflation target, then very long-term nominal bond prices may increase for that reason.

Effect of Paper Currency Below Par. Treating electronic money as the unit of account, however, means that the borrower may have an option to repay in paper currency when paper currency is cheaper than par. This could be the case with typical debt contracts, which are often ambiguous about how payments must be made. However, this problem can be easily addressed by legislation clarifying that debt contracts should be interpreted as referring to units of electronic (bank) money. Alternatively, debt contracts could include clauses to handle situations where paper currency is away from par. In the United States, the fact that gold clauses are again enforceable suggests that a clause insisting on payment according to an electronic money equivalent would be legally enforceable. ${ }^{10}$

\section{IS BREAKING Through THE ZERO LOWER BOUND DESIRABLE?}

\section{A. Costs and Benefits of Paper Currency Away from Par}

The most important consequence of breaking through the zero lower bound is that there is no longer any constraint on how low interest rates can go. We will turn to the costs and benefits of such an expansion of monetary policy options presently; it is worth briefly considering the costs and benefits of having paper currency being away from par that are distinct from the negative interest rates that this exchange rate between paper currency and electronic money enables.

\footnotetext{
10 That is, gold clauses serve as a precedent for electronic payment clauses. Quoting the "Gold clause" Wikipedia article:
}

Gold clauses specified within business contracts allowed the creditor the option to receive payment in gold or gold equivalents. A gold clause may prove valuable to the creditor in long term contracts, wherein questions may arise as to whether a currency in use at the time the contract was entered into would still have the same value when payment is due. Creditor concerns in respect to inflation, war, changes in government, and any other uncertainty about the future value of currency would be common reasons for adopting a gold clause within a contract.

These clauses were common at the beginning of the twentieth century. However, their use in the U.S. was invalidated by the Gold Reserve Act of 1934. Congress later reinstated their use for obligations (new contracts) issued after October 1977 in accordance with 31 U.S.C. 5118 (d)(2). On August 27, 2008, the United States Court of Appeals for the Sixth Circuit affirmed the enforceability of such clauses in the decision Jamaica Avenue, LLC vs. S\&R Playhouse Realty Co. 
The Psychological Cost of Paper Currency Away from Par. The most important cost of having paper currency away from par is a psychological cost. Anything that new is likely to worry many people, whether or not there is a good reason to worry. In an electronic money system, the paper dollar, euro, yen or pound that was at least symbolically the centerpiece of the old monetary system is being pushed to the periphery of the system. For those who viewed the paper dollar, euro, yen or pound as a solid anchor, this could create a sense of vertigo. This psychological distress, however little rational basis it has, is likely to translate into a political cost for the central bank, especially at the inception of the policy.

However, it is important to note that if paper currency is only a small distance away from par, the shift in its value may not be very salient to the typical household. For example, if a central bank wanted to gain 50 basis points leeway on the zero lower bound for one year only, it would require only a gradual rise in the paper currency deposit fee from zero to 0.5 percent and corresponding fall in the exchange rate from 1 to .995 over the course of a year, after which the exchange rate could hold constant and perhaps later gradually appreciate from .995 back to 1 . It is unlikely that this 0.5 percent fall in the value of paper currency would be passed through to customers in the type of retail purchases that they now normally make in paper currency. Thus, the fact that the paper dollar would no longer be the unit of account might not be fully salient to the typical household.

Moreover, the psychological costs of the displacement of paper currency from the center of the monetary system can be alleviated to the extent that a psychological attachment to the electronic dollar, euro, yen or pound can be created and fostered to compete with the psychological attachment to the paper dollar, euro, yen or pound.

The Computational Cost of Paper Currency Away from Par. Beyond the psychological cost associated with an attachment to paper currency and consequent queasiness about its being away from par, there would be some additional computational costs associated with a non-par exchange rate for paper currency. For businesses, this is much easier than many other accounting issues. For households, a surcharge on certain cash purchases is no more complex than sales taxes in the US, which are only assessed at the time of final salesomething that residents of the US have grown quite accustomed to. And even that cost is only incurred by households when there is pass-through.

Beyond the psychological queasiness and computational costs of paper currency away from par, one more significant cost is the unintentional distortion of the meaning of debt contracts and additional transactions costs incurred from physical transportation of paper currency if there is an option of making payments with below-par paper currency at face value. This cost can be avoided or greatly reduced in two cases: (1) if it is possible to pass a law stating that monetary amounts in all contracts should be interpreted as referring to quantities of electronic money or the equivalent in paper money at the current exchange rate; or (2) if the typical debt contract has a clause stating that this is how payments should be assessed whenever paper currency is away from par. 
The power of a decentralized approach of writing appropriate clauses in debt contracts should not be underestimated. If an international conference were convened this year by a central bank focusing on legal issues surrounding breaking through the zero lower bound, with both the legal teams from central banks around the world and the legal experts who design the boilerplate for standard debt contracts invited, it would be possible to get the word out to lawyers whose job it is to worry about even unlikely contingencies that paper currency away from par was a contingency they should worry about. If, as a result, the bulk of new debt contracts had clauses written into them to cover that contingency, it would not take very many years before most debt contracts in active force were immune from uncontemplated distortions due to paper currency away from par.

The Benefit of Being Able to Tax Paper Currency Without Inflation. On the benefit side of the ledger, the one important benefit we see to the possibility of paper currency being away from par other than removing the zero lower bound is that it makes the decision of how much to tax paper currency separable from the decision of the target inflation rate for prices in the unit of account. If there is a reason to tax paper currency, such as a tax system that is weak in other dimensions, or an association of paper currency with criminal activity or tax evasion, then the ability to tax paper currency without inflation could be valuable. The limiting case of this is if one wishes to make a transition to a fully cashless economy; one can experiment with higher and higher implicit rates of taxation on paper currency to see if anything goes amiss. If extremely high rates of taxation of paper currency do not cause serious problems, then it would indicate the possibility of completely abolishing paper currency.

\section{B. Costs and Benefits of Negative Interest Rates}

One aspect of breaking through the zero lower bound that cannot be honestly denied is that it takes off all restraints from interest rate policy. So it is important to look at the costs and benefits of the option of negative interest rates. ${ }^{11}$

\footnotetext{
11 The discussion below assumes a relatively responsible, independent central bank that worries about inflation being too high. The benefits and costs of negative interest rates are different for a more inflation-indulgent, less independent central bank. For a central bank tasked by the government with generating substantial seignorage to help balance the government budget, the option of seignorage without inflation could be very helpful in gaining that seignorage without the costs of inflation relative to the unit of account. For most central banks that succumb to the temptation of trying to chronically have a positive output gap, inflation is high enough that the zero lower bound is nonbinding in any case, so the option of negative interest rates would do no harm. The one case in which the option of negative interest rates coupled with an irresponsible central bank would do harm is the case of a central bank that had historically had the discipline to achieved a low inflation rate, but had turned from being responsible to being irresponsible about overly high inflation. But ever since the Great Inflation of the 1970s was conquered in many advanced countries, cases of central banks that achieved persistently low inflation rates and then relapsed to persistently high inflation rates are very rare. We are unable to think of an example. The greatest danger of such a relapse to high inflation is if high inflation were falsely thought to be the only way to effectively deal with the zero lower bound.
} 


\section{Direct and Indirect Benefits of the Option of Deep Negative Interest Rates: Economic Stabilization Power and the Benefits of Being Able to Revise the Inflation Target. The} direct benefit of being able to have negative interest rates is an additional option for economic stabilization. An indirect benefit is that of being able to lower the inflation target.

These benefits are both about removing costs of the zero lower bound. In addition to the direct costs of the zero lower bound and responses to a currently binding zero lower bound, there are costs from efforts to avoid running into the zero lower bound in the future. In particular, if there is any fear of these direct costs of the zero lower bound, central banks are likely to choose long-run inflation targets that are higher than they would otherwise choose in order to take into account the danger from these direct costs. The zero lower bound should not be taken as a given. But if it is, many find the logic behind tilting the inflation target higher to steer away from the zero lower bound compelling. Ben Bernanke gave the conventional view for an inflation target at 2 percent rather than zero in his March 20, 2013 press conference, saying:

\section{... if you have zero inflation, you're very close to the deflation zone and nominal interest rates will be so low that it would be very difficult to respond fully to recessions. And so historical experiences suggested that 2 percent is an appropriate balance ...}

(Note that in talking to the press, the word "deflation" is often used to point to problems with the zero lower bound. In the absence of a zero lower bound, mild deflation might not be much worse than mild inflation.)

The Costs of Inflation in the Absence of a Zero Lower Bound. To clarify the likely benefits of revising the long-run inflation target when the zero lower bound is no longer a concern, it is important to reexamine the costs and benefits of inflation in this new environment. Such a reexamination is needed because in some sense there would be two inflation rates in the picture: the inflation rate proper, which is the inflation rate relative to the unit of account, and the "inflation rate" relative to paper currency.

The perspective of two inflation rates yields an important answer to those who argue that raising the long-run inflation target within the current monetary system is better than maintaining or lowering the long-run inflation target but periodically allowing paper currency to go away from par. Letting paper currency go away from par makes it possible to have the "inflation" relative to paper currency necessary to steer clear of the zero lower bound as needed without requiring inflation relative to the unit of account. And as we now proceed to argue, it is inflation relative to the unit of account that generates all substantial costs of inflation, not inflation relative to paper currency, when that is distinct from inflation relative to the unit of account.

First, consider the costs of having microeconomic relative prices away from what they should be because of staggered price setting. These are costs that arise from inflation relative to the unit in which prices are set, which for almost all goods is likely to be the unit of account. These costs are incurred whether the price in question is for varieties of final goods, for varieties of intermediate goods, for varieties of labor, or for labor over time. 
Second, consider menu costs. These are incurred when prices are changed. Like the costs of messed-up relative prices, menu costs are incurred more often when there is non-zero inflation relative to the unit of price setting, which will typically be the unit of account.

Third, consider costs (and perhaps sometimes benefits) of confusion. These may be the most serious cost of inflation. Some examples are people blaming "inflation" for real wages lower than they would like, unintended distortions in the tax code such as higher capital taxation than legislators thought they were voting for because they were implicitly thinking in terms of zero inflation, misunderstanding economic data such as inequality numbers that include the inflation component of interest rates as if it were real income, people mistaking nominal for real rates of return in their retirement planning, and muddling intertemporal historical comparisons more generally.

Fourth, consider unpredictability. This has to do with inflation relative to the unit of account.

Finally, consider shoe-leather costs. As discussed above, these are not about inflation at all, but about the spread between the deposit rate and the paper currency interest rate, which in an electronic money system is a separate decision variable of the central bank that can be chosen separately from the inflation rate. Indeed, as mentioned above, it is possible to follow the Friedman rule of equating the paper currency interest rate to the target rate or deposit rate at all times to avoid underuse of paper currency, regardless of the inflation rate relative to the unit of account. Mechanically, these shoe-leather costs are a function of the "inflation" rate relative to paper currency, but only in comparison to other interest rates at any moment. The bottom line is that the key costs of inflation stem from inflation relative to the unit of account. There are some exceptions. For example, it is possible that some retailers might have a separate paper currency price for candy bars rather than using the electronic price times the store's general cash surcharge factor. If so, then candy bar inflation relative to paper currency would matter even apart from candy bar inflation relative to the electronic unit of account. Also, if there was some diversity of the cash surcharge factor from store to store, that could have an adverse effect on some microeconomic price signals. However, because this surcharge factor would typically be a single number for each store, it might become standardized across stores by competitive pressures to a greater extent than individual prices on goods are.

The Benefits of Inflation. We can think of four possible benefits of inflation. The first two have to do with supposed benefits of nominal confusion: greater capital taxation than could be otherwise legislated (if that is indeed a benefit rather than a cost) and making it easier for firms to cut workers' real wages without the workers fully realizing and resisting that (or having an institutional rule resist it for them, as for tenured professors). The third is the interaction between time-discounting and the determination of the Calvo reset price: firms care a bit more about getting the right relative price in the near term than in the farther term, so in an inflationary environment they shade their reset price slightly lower. If it is a union setting wages, and the union has quasi-hyperbolic discounting, the effect can be made stronger. (See Graham and Snower, 2011.) Fourth, higher inflation may interact with certain financial market customs in a positive way. For example, the expected speed of repayment is 
often linked to nominal interest rates, and a higher expected speed of repayment of loans may make it harder for Ponzi schemes to prosper.

Although the benefits of inflation may make the optimal level of inflation strictly positive even in the absence of the zero lower bound, being able to lower the inflation target is unambiguously beneficial as long as the optimal inflation rate in the absence of the zero lower bound is below the current inflation target of, say, 2 percent. It is only if the inflation target in the absence of the zero lower bound is as high as 2 percent that there is no benefit from this adjustment.

By contrast, whatever the true optimum long-run inflation target might be in the presence of the zero lower bound, it seems unlikely that many central banks would brave a still present zero lower bound by lowering their inflation target, and most central banks worry that raising the inflation target is hard to do without losing hard-won credibility against inflation even higher than the new target. So for many central banks, any adjustment of the long-run inflation target seems fraught with danger as long as the zero lower bound remains in force.

One More Cost of Nonzero Inflation and a Prediction. Even in the absence of a zero lower bound, standard models of optimal monetary policy suggest that price-level targeting is beneficial relative to inflation targeting. But a price-level targeting policy can be hard to communicate in an inflationary environment where inflation is salient since price-level targeting involves "catch-up inflation" if inflation has been too low for a while and "catchdown" below-normal inflation if inflation has been too high for a while.

By contrast, if inflation is zero, price-level targeting is easy to explain: return to the previous level of prices. Because of this communications advantage, a central bank with a zero longrun inflation target might find it easier to implement price-level targeting.

Given the communications advantage of absolute price stability (a zero inflation target and price-level targeting) and the benefits of inflation very close to zero understanding intertemporal comparisons over long spans of time, we predict that in fact, if the zero lower bound is broken, that many central banks will choose to have target inflation rates of zero, despite some concerns about the possible benefits of positive inflation listed above. (Of course, a realistic possibility of targeting "zero" inflation would inspire a great deal of additional research on biases in different measures of inflation.)

Other Costs of Negative Interest Rates. Many people worry about interest rates that are too low. A distinction needs to be made between temporarily low interest rates and chronically low interest rates. One possible cause of chronically low short-term interest rates and associated low long-term interest rates is being up against the zero lower bound with a continuing output gap that depresses the real rental rate for investments. To put it bluntly, if the markets believe there is a good chance one might be headed for one's own version of Japan's lost decades, they may see low interest rates far off into the future for a nation stuck at the zero lower bound. 
By contrast, if the markets become convinced that the zero bound has been effectively broken, and that a central bank will vigorously use negative interest rates to bring the output gap to zero, they will predict interest rates in the future that are appropriate to the higher real rental rate for investment in a non-depressed economy.

For most of our discussion, as long as monetary policy matters in a model, the specific business cycle model considered does not matter that much for the argument here because adding more monetary policy options is unambiguously good as long as a central bank is wise in using those new options. But the idea that in a recession interest rate cuts are the path to higher interest rates does depend on the particular business cycle model one has in mind.

Basu and Kimball (2003) argue that investment planning adjustment costs can explain the lag in the effect of interest rate policy on economic activity. But any model that (a) can explain the lag in the effect of the central bank's target rate on economic activity and (b) has the level of economy activity affect interest rates, implies that an initial interest rate cut will lead to a different level of interest rates after economic activity has adjusted. Thus, there is no paradox to the claim that interest rate cuts might lead to higher interest rates: the difference would be in what a shift in monetary policy does before economic activity has adjusted and what it does after economic activity has adjusted to that policy.

Kimball (1995) shows in a basic dynamic sticky price model with Q-theory-type investment smoothing that the extent to which the real interest rate can differ from the real rental rate net of depreciation depends on how long a business cycle lasts: the longer the cycle, the closer the real interest rate has to be to the net rental rate (because the capital gains rate term in the Q-theory Euler equation is smaller when things are moving more slowly). Therefore, in the kind of long-lasting recession one might fall into when up against the zero lower bound, the real interest rate needed for positive investment (or more generally for positive generic investment in the sense of Kimball, 2014), will tend to be quite low. On the other hand, economic recovery will tend to raise the interest rate relative to what it was during a longlasting recession.

Considering the claim that interest rate cuts below zero might raise interest rates once investment has adjusted is important in evaluating many posited costs to negative interest rates. For example, consider financial stability. It is not ridiculous to think that low long-run interest rates that raise fundamental present values might also lead to larger divergences from fundamental prices as mistaken expectations are run through the present-value formula. But if negative interest rates are a path to higher long-run interest rates, they would tend to damp down this mechanism of financial instability.

More generally, to criticize negative rate policy, it is not enough to argue that low interest rates are bad, it is also essential to know whether lower interest rates are the path to higher interest rates, and if so, which interest rates matter most for whatever cost of low interest rates is claimed.

This complication can go both ways. If (contrary to our own views) low long-run interest rates are good - for example to maintain solvency for a high-debt country such as Japan, then 
negative short-term rates might be a problem because they bring a booming economy that raises long-run interest rates.

\section{What Does it TAKe to Break Through The Zero LOWER BOUND?}

We have argued that a very specific policy can break through the zero lower bound. In this section, we want to identify what is essential and what is not essential for breaking through the zero lower bound in the way we have described.

\section{A. What If the Government Has Trouble Establishing Electronic Money as the Unit of Account?}

To begin with, although theoretical models will often make the unit of account indeterminate, there are strong arguments that the government can, in fact, determine what the unit of account is. Historically, an important source of units of account was in rules defining tax obligations. The government can mandate a certain standard of tax accounting, and accounting used in adjudicating contracts in court. Moreover, just as the government can point to an equilibrium for the details of daylight savings time and most people follow the suggested equilibrium in order to coordinate with everyone else, within reason the government can probably determine the unit of account simply by pointing to a particular equilibrium. Among genuine equilibria, typically whichever equilibrium the government points to is likely to become focal.

But what if the electronic dollar is not, to begin with, fully used as a unit of account? One simple point is that if inflation expectations are anchored in terms of the electronic dollar, and inflation inertia is in terms of the electronic dollar, then one can definitely make the lower bound non-binding by depreciating paper currency relative to electronic money. This is true even if people are using a messy mix of the electronic dollar and the paper dollar for price setting and for accounting.

The more difficult case is if inflation inertia is in terms of inflation relative to paper money. Then depreciating paper currency does not provide any leeway vis à vis the zero lower bound. (However, it doesn't make things worse.) If, to begin with, people are mostly using paper currency as a unit of account and inflation inertia is in paper, the central bank still has a good chance of inducing a long-run shift towards electronic money as the unit of account if it rewards people for holding money in electronic accounts by having the electronic interest rates quite a bit higher than the paper currency interest rate. That is, if people are relying on paper more than seems desirable, the central bank can make its rate of return lower relative to electronic accounts.

If electronic accounts have a significantly higher rate of return than paper currency, from the perspective of paper as the numeraire, it is a bit as if the government were doing a helicopter drop, but only in proportion to people's electronic accounts. However, the beauty of this kind of helicopter drop is that it is not a helicopter drop in the long-run equilibrium that the central bank is trying to reach. The money supply would be increasing dramatically relative to the paper dollar, but not relative to the electronic dollar that the government is hoping to get people to ultimately use as the unit of account. In a sense, it is like a helicopter drop out of 
equilibrium with all the advantages of a helicopter drop (stimulating the economy), but not a helicopter drop in equilibrium, thus avoiding the biggest disadvantages of a helicopter drop (destroying anti-inflation credibility or adding to the national debt).

The issue of whether the government can effectively determine the unit of account can be illustrated nicely by thinking about the possible use of a variant on our proposal for bringing down an inflation rate in what we will call the "peso" from, say, 7 percent per annum to zero at low cost. Suppose a central bank with a high inflation rate from the past had established credibility for not trying to exceed the natural level of output. Suppose in addition, that in conjunction with the rest of the government, it could determine the unit of account, with inflation inertia focused on that unit of account. Then in Phase 1 of the disinflation program, it could simply stay at the natural level of output, keep the paper peso as the unit of account, and appreciate the electronic peso relative to the paper peso according to a price index at close to 7 percent per year. (This is actually closer to Robert Eisler's original 1932 proposal than what we have discussed above, except that Eisler betrays no notion of the natural rate view we assume here.) Then, once firms and households had become used to zero inflation in the electronic peso, so that expectations for inflation relative to the electronic peso were firmly anchored around zero, in Phase 2, firms could be encouraged to switch to setting electronic prices for goods and using it as a unit of account.

If the stipulation of credibility in not trying to go above the natural level of output is met, we suspect that such a program could succeed in lowering inflation from 7 percent per year to zero without much larger deviations from the natural level of output than would have happened with a steady 7 percent inflation target. If this seems at all plausible, it betokens enough government power over the unit of account that other governments inheriting lower inflation rates from the past should have no trouble accomplishing the much easier task of making a unit of account that is ambiguous between paper currency and electronic money (because they are at parity) into an electronic money standard. Empirically, the history of currency reforms (many of which have been quite successful) provides guidance about how difficult such shifts in the unit of account are to engineer.

\section{B. Avoiding Paperization by Avoiding Prolonged Use of Negative Interest Rates Without Lowering the Paper Currency Interest Rate Below Zero}

One danger of prolonged zero or negative interest rates while keeping paper currency at par is that this has the potential to encourage greater use of paper currency and thereby make the transition to electronic money more difficult. "Paperization" in the sense of a large increase in the fraction of transactions done in paper currency may not happen overnight, but the prominent role of paper currency in transactions in Japan and Germany indicates what enough decades of a zero spread of deposit rates over paper currency can do to transactions customs. A large negative spread of deposit rates over paper currency could result in paperization akin to that seen in Germany and Japan over a shorter time horizon. Higher transition costs because of paperization are not sufficient reason to dismiss the option of electronic money for Japan and Germany (and the countries that share monetary policy with Germany), but rather are a reason to proceed, where possible, with the transition relatively early on, before countries have gone through such a paperization process. 


\section{Figure 6. Ratio of Currency in Circulation to Nominal GDP}

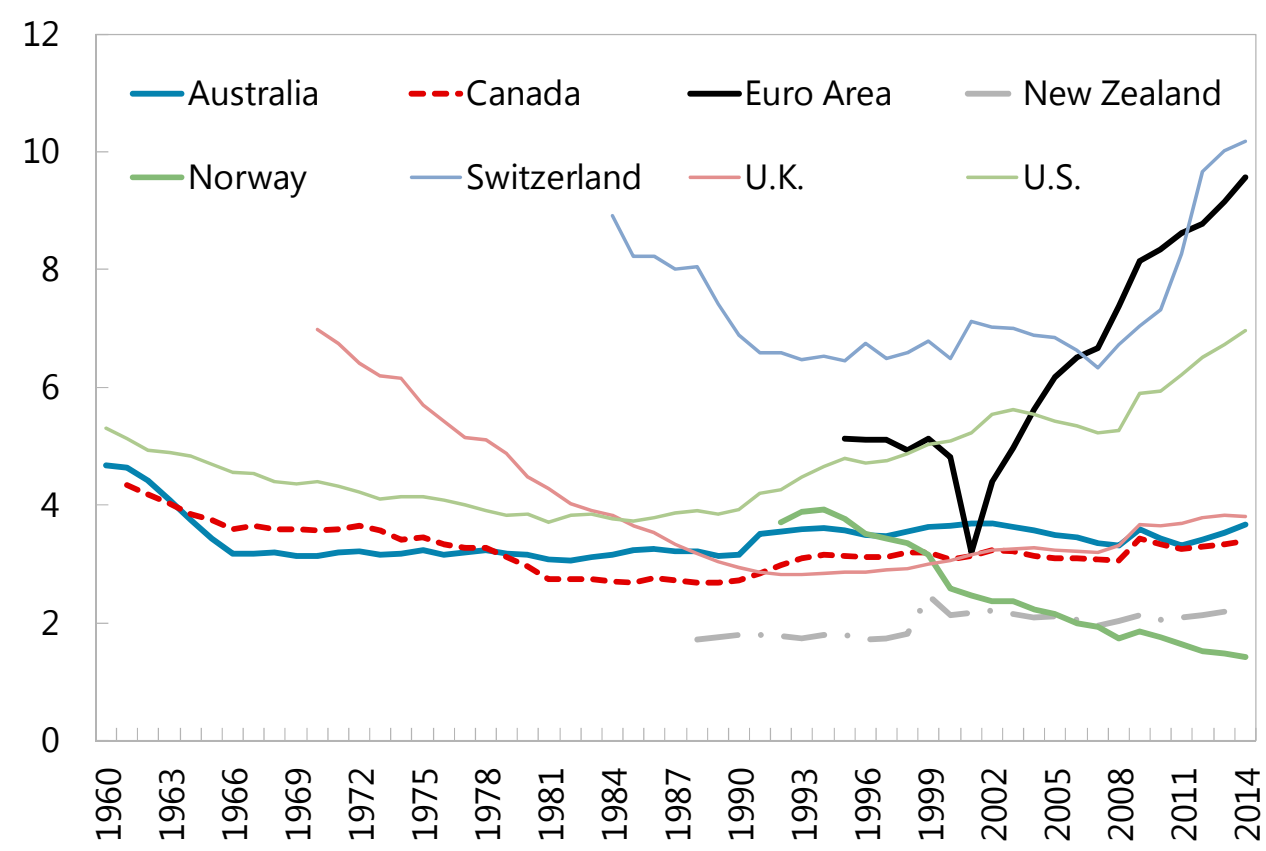

Sources: Haver Analytics

To avoid threatened paperization when the target rate is negative, the central bank can choose a large enough spread between the target rate and the paper currency interest rate to avoid paperization when paper currency is not at par. By lowering the paper currency interest rate far enough below other short rates, the central bank can make it more attractive to hold electronic money relative to paper currency. And those who hold as little paper currency as possible because it has a lower return will want to use electronic money for many transactions. Thus, there is reason to hope that any tendency toward paperization in a negative interest environment can be counteracted by a large enough spread of electronic interest rates over the paper currency interest rate. Note that the interest rate spread for electronic money over paper currency need not be widened until and unless there are signs of paperization. It is easy to adjust the paper currency spread in a data-dependent way.

In addition to the overt spread between paper currency and electronic money, central banks also often influence the balance between use of paper currency and electronic money by effectively subsidizing the handling of paper currency. When Sweden reduced the number of locations for cash windows, thereby forcing banks and other firms to take on more of the costs of transporting paper currency, it led to an increase in the frequency of electronic transactions. (Of course, changing the costs of handling paper currency also has implications for pass through of the exchange rate for paper currency.) 


\section{Can Things Other than Paper Currency Create a Zero Lower Bound?}

Any government borrowing rate that is stuck at zero can create a zero lower bound.

Therefore, along with the paper currency interest rate, it is important to lower the target rate, the interest on reserves and the rate that the government pays for deposits. To this list, one can add the importance of lowering the interest rate applied to excess tax payments carried over from one tax year to the next. (That happens to be current US law: by law the betweentax-year interest rate is set by the Secretary of the Treasury in line with other short-term interest rates. The interest rate is zero within a tax year, but once all tax payments are made on the first day of the tax year, there is no further way to arbitrage using that zero rate within a tax year. See Christian Kimball and Miles Kimball, 2015 for the nuances of this description of current U.S. law.) If there are any other options for lending to the government that private agents can take advantage of in an unlimited way, the relevant interest rates for those other forms of government borrowing must also be lowered.

It is hard for any other agent than a government to generate a zero lower bound, since one has to have very deep pockets and a disregard for profit and loss to be willing to provide enough in the way of zero interest rates when interest rates are generally negative to push the market rate up most of the way to zero.

Another simple test rules out most assets from being able to create a zero lower bound. If any asset can adjust its price, lower interest rates or the combination of negative interest rates and the effects of paper currency off par on the payment stream will simply change the price of the asset without in any way guaranteeing a return above negative market rates. In theory, the price of many assets (such as gold) should appreciate, and then face expected depreciation. But in any case, the return of an asset whose price can vary will be risky and so will not provide the kind of riskless arbitrage opportunity that paper currency provides when there is a commitment to keep it at par.

\section{What If Paper Currency Is Still Legal Tender?}

Debt contracts are a special case of an asset whose price can change. Once one realizes that the face value of a debt contract is not its market value, it becomes clearer that preexisting debt contracts cannot create a zero lower bound. Debt contracts cannot be cloned. In a new situation, the market will determine new prices or new terms.

Legal tender does matter in other ways, however. As alluded to above, unintended effects on debt contracts are an undesirable side effect of both interest rate movements and paper currency away from par.

Even if paper currency is legal tender in name only because debt contracts specify payment in an electronic equivalent (with use of paper currency for payment only at the exchange rate), there is still symbolic importance to an inscription on paper currency saying that it is legal tender. To those who don't know the difference, that sounds all too much like saying that the paper dollar, euro, yen or pound is the unit of account. To put things another way, anything that raises the prestige of electronic money can help bolster its use as a unit of account, and anything that lowers the prestige of paper currency can help reduce the 
temptation to treat it as the unit of account. The importance of raising the prestige of electronic money to bolster its use as the unit of account is one good reason to call the policy we advocate an "electronic money" policy.

\section{E. The Role of Transactions Share in Bolstering Electronic Money as the Unit of Account}

Anything that raises the fraction of all transactions made in electronic form (beginning with credit or debit card payments and electronic transfers, but also including checks) is helpful in making a transition that demotes paper currency easier. Here a trend toward an increased fraction of transactions fees that are rebated to the one using a card may ultimately be quite powerful. Further down the road, a reduction in the transactions fees themselves (through innovation that disrupts the credit and debit card oligopoly) could lead merchants to encourage greater card use.

According to a recent survey of consumer cash usage conducted between 2009 and 2012 (Bagnall et al., 2014), cash usage is still high in advanced countries when measured in volume of transactions, but much lower when measured by value of transactions. This was driven by the relatively high usage of card payments for larger-sized transactions. That is, consumers were mainly using cash for relatively small transactions. Also, in this period, payment card ownership rates were very high in all the countries surveyed (above 80 percent), suggesting that innovations in payment systems for small transactions could swiftly increase the fraction of transactions made in electronic form. 
Figure 7. Cash and Payment Card Usage

Payment Share by Volume (Percent)

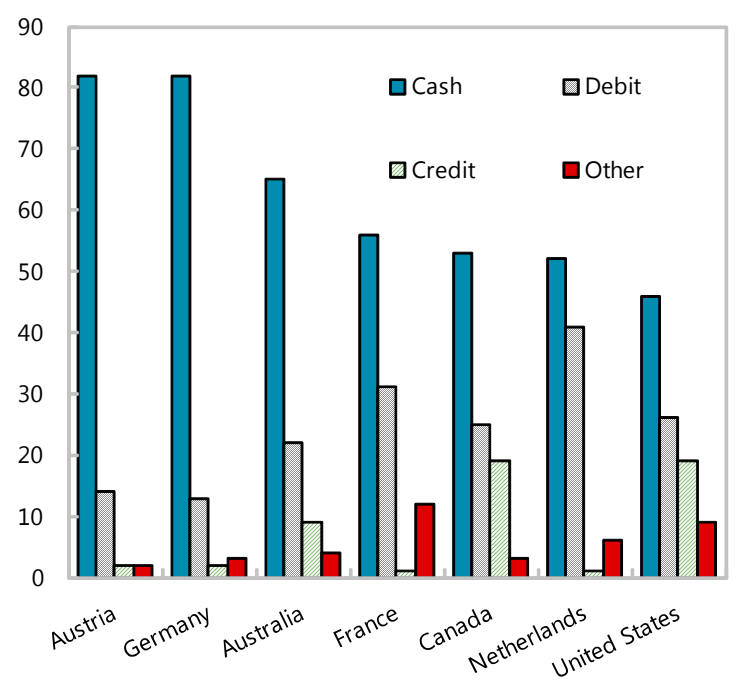

Average Transaction Values (PPP-Adjusted USD)

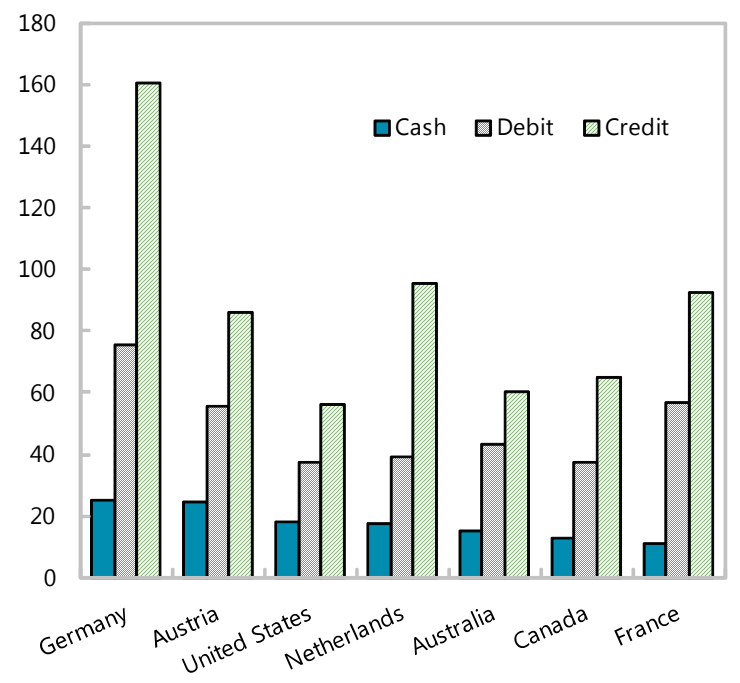

Payment Share by Value

(Percent)

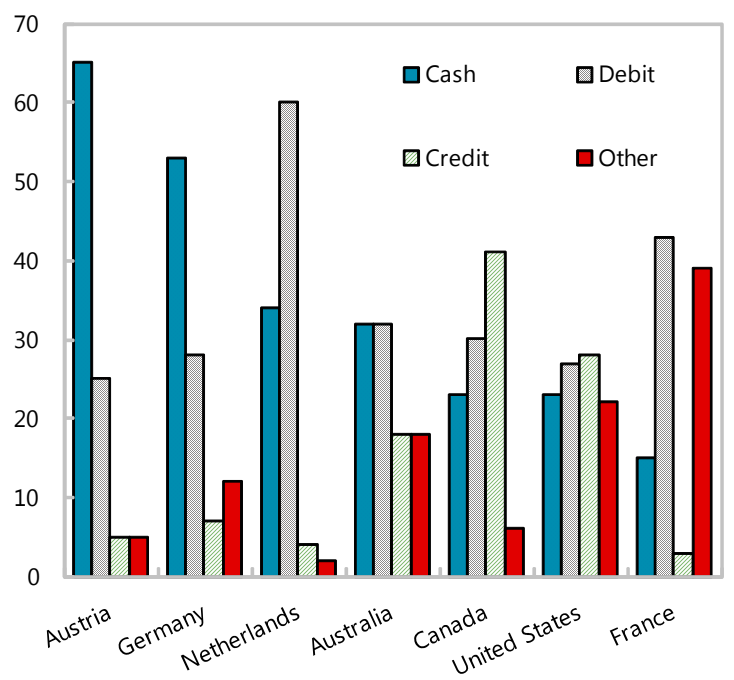

Ownership of Payment Cards (Percent)

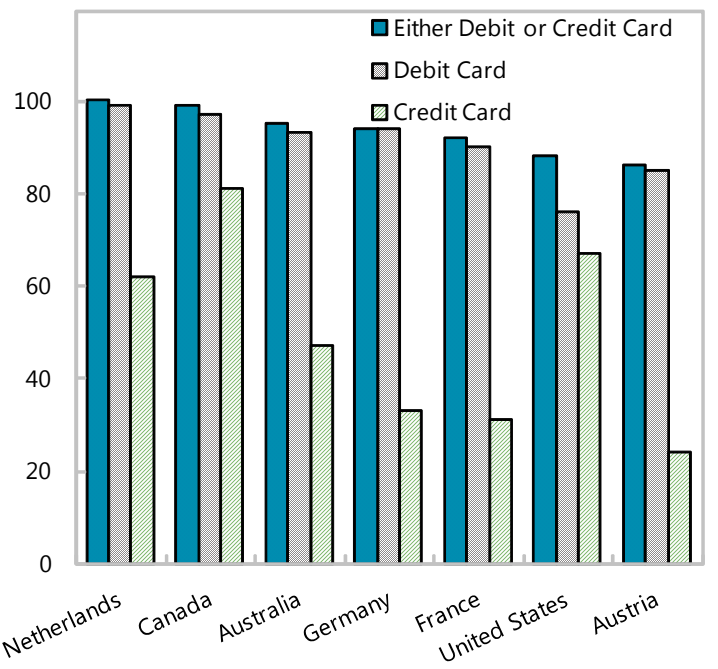

Source: Bagnall et al. (2014) 


\section{Misconceptions About Eliminating the Zero Lower Bound}

Below we discuss fifteen misconceptions about eliminating the zero lower bound, and connect it to our discussion above. We disagree with each of the bolded statements, as detailed after each.

1. "Eliminating the zero lower bound is unnecessary": According to some observers eliminating the zero lower bound is unnecessary since the combination of fiscal policy, quantitative easing, and other monetary policy tools such as forward guidance or nominal GDP level targeting is sufficient to stimulate a recovery at the zero lower bound. A similar line of argument also suggests that we should avoid experimenting with expanding the toolkit since the economy will fix itself. However, the experience of the lost decades in Japan, and the recent experience of advanced countries facing the zero lower bound with persistent deflation or low inflation suggest that the combination of existing tools used has not been sufficient to bring about a recovery anywhere near as quickly as desirable, and that the welfare costs of such episodes can be quite large.

Here, it is worth mentioning issues with fiscal policy and quantitative easing in particular. Fiscal policy has two main problems. First, cutting taxes or raising spending adds to the national debt. Second, while many countries have technocratic monetary policy institutions, no country has similarly technocratic fiscal policy institutions (other than "automatic stabilizers," which were clearly not enough on their own to avoid a serious recession after the financial crisis). If monetary policy can be empowered, central banks are reasonably well set up to make appropriate decisions for stabilization.

There is a political economy reason why it is difficult to make fiscal policy technocratic: taxing and spending are relevant not only for short-run stabilization but also for long-run issues of incentives, redistribution and government spending priorities. Although the shortrun and long run use of fiscal policy can in principle be distinguished, it is not surprising that in fact the two different roles of fiscal policy — short-run and long run — are tangled up politically.

As for quantitative easing, like fiscal policy, quantitative easing was not in fact used in high enough dosages to get satisfactory monetary policy outcomes. The outcomes were better than they might have been otherwise, but not good in any absolute sense. Scaling up quantitative easing does not necessarily yield unlimited monetary stimulus power, since the effect of higher quantities on the relevant spreads may reach an asymptote. Second, although somewhat modified spreads may be a positive change even apart from monetary policy, spreads that are far enough from the historical average could easily have undesirable side effects. Third, we simply don't understand quantitative easing very well. In simple models, quantitative easing does nothing, for Modigliani-Miller/Ricardian Equivalence type reasons. The exact effects of quantitative easing, which would need to be understood in order to assess costs and benefits of scaled-up quantitative easing, depend on the particular model used to escape the equivalence benchmark. 
By contrast, simple models say that it is only real interest rates that matter-which if true implies that past experience can provide excellent guidance for the effect of negative nominal rates within an important range. For negative interest rates, the real-world counterparts to nonstandard model elements are a worry, but not the essence. For quantitative easing, the real-world counterparts to nonstandard, little-understood model elements are everything. Empirically, we know the amount of quantitative easing actually used was insufficient to yield quick recovery; we simply don't know what larger doses of quantitative easing would have done. Moreover, we don't have adequate theory to know the extent to which a lower inflation rate (and therefore tighter zero lower bound) as in Japan affects the potency of quantitative easing. So it is hard to generalize empirical results between very low inflation economies such as Japan and other countries that have used quantitative easing.

2. "Policymakers can't do anything about the zero lower bound": The zero lower bound is a policy choice, not a law of nature (see Section II above).

3. "Eliminating the zero lower bound requires either abolishing paper currency, or doing something physical with each bill of paper currency (e.g., affixing tax stamps, installing electronic strips in paper bills, etc.)": There are ways to eliminate the zero lower bound by attacking the incentives for massive paper currency storage that allows a government to keep paper currency in its current physical form (see Section II.B above).

4. "To eliminate the zero lower bound, it is necessary to either attack storage directly-by making large scale storage illegal, or by making paper currency scarce, or to inhibit withdrawals with restrictions or a fee": Under the mechanism described in this paper - a time-varying deposit fee-there is an effective exchange rate between paper currency and reserves, with banks allowed to freely exchange in either direction, with no storage or withdrawal restrictions. (Indeed, withdrawals would not only be unrestricted, but would sometimes be at a discount.) The deposit fee is only between the central bank and private-sector banks, and no regulations related to the deposit fee are needed beyond that (see Section II.B and II.C above).

5. "Detailed regulations for banks and retail shops would be needed to eliminate zero lower bound": Under the implementation described above, banks and shops can and should be allowed to choose any exchange rate they choose. Market forces will cause the exchange rate between paper currency and electronic money (i.e., reserves or bank money) to hold throughout the banking and financial system (see Section II.B and II.C above), but retail shops would in practice have leeway in their exchange rate pass-through decisions.

6. "Even at modest doses, negative interest rates will dramatically change the daily experience of regular households." Based on the fact that despite paying 2 percent to 4 percent in credit card and debit card fees, retail shops often charge the same for cash and for credit/debt transactions, they may accept paper currency at par even if paper currency is running up to 4 percent or 5 percent below par. If paper currency went deeper below par, cash surcharges would be likely to be implemented by retailers gradually, with some stores moving before others. These surcharges could be handled at the register in much the say sales taxes are now, but only on cash purchases. 


\section{7. "Implementing the time-varying deposit fee requires a totally new way of} thinking about monetary policy": As Section II.B discusses, implementation essentially requires the central bank to set one more interest rate at regular meetings - the paper currency interest rate - in addition to the target rate, interest on reserves and lending rate. This does not require any other change to implementation of monetary policy, and in fact may simplify monetary policy since it removes the need for quantitative easing or forward guidance for stabilization.

In particular, to emphasize how much remains unchanged for monetary policy even when the zero lower bound is eliminated, breaking through the zero lower bound is fully compatible with using open market purchases and sales of short-term Treasury bills as the central tool of monetary policy. A negative Treasury bill rate corresponds to a price for a Treasury bill above the principal returned at maturity. The time-varying effective exchange rate between paper currency and electronic money at the cash window of the central bank is simply a way to get paper currency out of the way. This is analogous to a central bank needing to cut interest on reserves when it cuts the target rate. Otherwise, the option of holding excess reserves would interfere with lowering the target rate.

8. "The electronic money system involves significant costs even in 'standby mode' when there is no need for negative interest rates": As Section II.C shows, except during the period of negative interest rates and a period of gradual return to par thereafter, the electronic money system looks much like the current system. This is because when negative interest rates are no longer needed paper currency can be at par again with electronic currency, like in the current system.

9. "An electronic money system requires a stronger ability to commit than regular monetary policy": As discussed in section II.B, the paper currency interest rate is given by an overnight commitment to exchange one unit of paper currency for $\mathrm{X}$ units of electronic money tomorrow. Such an overnight commitment is likely to be fully credible. In addition, to avoid problems, the central bank needs to commit to keep the paper currency interest rate at or slightly below the target rate. This is easily credible since it is obviously disruptive to have the paper currency interest rate far above the other rates. The other commitment problem the central bank faces is that of not overheating the economy too much by keeping rates too low, but this is the same commitment problem faced by central banks in the current system.

10. "An electronic money system disadvantages cash and the unbanked": This is not true, since during periods of negative rates, the paper currency interest rate can be kept very close to the target rate, thereby having no differential impact on the unbanked. The one exception is discussed in Section V.A. Moreover, eliminating the zero lower bound would likely allow a reduction in the long run inflation target, which would benefit those who rely on the cash economy. In this context, the central bank could follow the Friedman rule regardless of inflation rate if it is willing to let paper currency go above par (see Section II.C).

\section{1. "Deep negative rates are not enough if the banks are messed up as they were} during the Great Recession": Any finite risk or liquidity premium can be countervailed by deep enough negative rates. For example, housing construction will kick in at some point. 
Moreover, open-economy effects can be quite powerful by stimulating exports through the international capital flow/exchange rate channel. In extreme cases, storage of physical goods can provide needed stimulus to return to the natural level of output if interest rates fall far enough.

\section{2. "Even if paper currency is defanged, other things would generate a zero lower}

bound": As long as the paper currency interest rate and all other government borrowing rates go negative in tandem, nothing else will stop negative interest rates from going into deep enough negative territory.

Private firms are unlikely to offer zero interest rates when market interest rates are deep in negative territory. Also, any asset whose price can fluctuate can go up enough in price in the face of negative interest rates to have a return low enough to be consistent with negative safe rates. This applies to preexisting debt contracts, foreign currency, gold, or even preexisting gift cards redeemable at par including those redeemable for an electronic refund at par.

The ability to get a zero interest rate through the tax system can be (and is in the United States) limited to prepaying within the tax year. The value of this prepayment option is limited in present value to avoiding roughly half a year's negative interest on a typical year's tax liability (unless income tends to come especially late in the tax year).

An interesting case study showing how difficult it is for something other than paper currency or another government borrowing rate to create a zero lower bound is to consider forever postage stamps. Forever postage stamps a zero real interest rate built in, but they have not generated a zero real lower bound because they cannot be turned in for a refund in unlimited quantities. Moreover, issuance could cease at any time, making them an asset that could float in price.

\section{3. "Negative rates would unavoidably cause financial instability": Even if low} interest rates are detrimental to financial stability, temporarily negative interest rates could actually help by raising long-term rates. Nevertheless, just in case, it is important to pair negative interest rates with progressively higher equity (capital) requirements in the form of high capital conservation buffers. This would ensure that business mistakes in a new negative rate context are made at the banks' or firms' own expense, and not the taxpayers'. Also, having the stimulative power of negative interest rates on tap makes it unnecessary to get extra aggregate demand by allowing financial bubbles - contrary to Larry Summers's suggestion at the November 8, 2013 IMF Economic Forum (See Kimball, 2013). So there is no aggregate demand reason not to aggressively pursue higher equity requirements for banks if the zero lower bound is eliminated.

14. "Stimulative monetary policy distracts from supply-side reforms": Although this is logically possible, there are reasons to doubt that stimulative monetary policy distracts from supply-side reforms under current circumstances. We suspect that the knowledge that more demand-side stimulus is needed can distract from supply-side reforms at least as much as having stimulative monetary policy. Many supply-side reforms require reallocation of labor and capital—something that typically looks too painful to insist on in a recession when unemployment is high and businesses that were healthy in normal times are failing. Also, 
governments that end recessions quickly gain the credibility to implement tough reforms. Moreover, monetary stimulus avoids the increase in national debt that can distract from or directly interfere with supply-side reform (for example, by higher taxes or less scientific research).

15. "It will never happen": Something of equivalent magnitude happened in the twentieth century: the end of the gold standard. Moreover, the experience of quantitative easing shows that central banks have the ability to implement policies that were previously seen as quite radical. The politics of eliminating the zero lower bound is different in different countries and different situations. Once one central bank blazes the trail, it is much easier for others to follow. And the international capital flow/exchange rate effects for early adopters will encourage other countries to break through the zero lower bound as well, in order to be able to neutralize those effects on net exports or on overall aggregate demand with their own interest rate policy.

\section{Conclusions}

Eliminating the zero lower bound has some costs, but those costs should be weighed against the benefits: not only ending recessions, but also ending inflation. The key analytical point is that by and large the costs of inflation are costs of inflation relative to the unit of account. Thus,

$>$ if electronic money provides the unit of account (including the unit of account for price and wage setting),

and inflation is close to zero in terms of the electronic unit of account,

then one can have inflation relative to paper currency without serious costs,

$>$ as long as the central bank keeps the spread between the paper currency interest rate and the checking account interest rate small.

As a way to eliminate the zero lower bound, a time-varying paper currency deposit fee has the great advantage that it can be implemented solely by action at the cash window of the central bank. There are many other complementary policies that would be useful in conjunction with this central mechanism (detailed in Appendix I), but it is the effective exchange rate between paper currency and electronic money at the cash window of the central bank that makes the paper currency interest rate an easily controlled policy variable of the central bank. Such an ability to vary the paper currency interest rate along with other key interest rates (which can be modified by standard means, even in negative territory), makes it possible to stimulate investment and net exports as much as needed to revive the economy, even when inflation, interest rates, and economic activity are quite low, as they are currently in many countries. 


\section{REFERENCES}

Barsky, R., House, C., and Kimball, M., 2007, "Sticky-Price Models and Durable Goods," American Economic Review, 97 (June), pp. 984-998.

Basu, Susanto, and Miles Kimball, 2003, "Investment Planning Costs and the Effects of Fiscal and Monetary Policy," unpublished, University of Michigan.

Buiter, Willem H. and Nikolaos Panigirtzoglou, 2001, "Liquidity Traps: How to Avoid Them and How to Escape Them," with Nikolaos Panigirtzoglou, in Reflections on Economics and Econometrics, Essays in Honour of Martin Fase, edited by Wim F.V. Vanthoor and Joke Mooij, pp. 13-58, De Nederlandsche Bank NV, Amsterdam.

-, and Nikolaos Panigirtzoglou, 2003, "Overcoming the Zero Bound on Nominal Interest Rates with Negative Interest on Currency: Gesell's Solution," Economic Journal, Volume 113, Issue 490, October 2003, pp. 723-746.

— 2004, "Overcoming the Zero Bound: Gesell vs. Eisler; Discussion of Mitsuhiro Fukao's 'The Effects of 'Gesell' (Currency) Taxes in Promoting Japan's Economic Recovery," discussion presented at the Conference on Macro/Financial Issues and International Economic Relations: Policy Options for Japan and the United States, October 22-23, 2004, Ann Arbor, MI, USA. International Economics and Economic Policy, Volume 2, Numbers 2-3, November 2005, pp. 189-200. Publisher: Springer-Verlag GmbH; ISSN: 1612-4804 (Paper) 16124812 (Online).

_ 2007, "Is Numérairology the Future of Monetary Economics? Unbundling Numéraire and Medium of Exchange Through a Virtual Currency With a Shadow Exchange Rate," Open Economies Review, Publisher Springer Netherlands; ISSN 0923-7992 (Print); 1573-708X (Online). Electronic publication date: Thursday, May 3, 2007. See "Springer Website."

_ $2009 \mathrm{a}$, Negative Interest Rates: When Are They Coming to a Central Bank Near You? ft.com/maverecon, May 7, 2009.

— 2009b, The Wonderful World of Negative Nominal Interest Rates, Again. ft.com/maverecon, May 19, 2009.

_ 2009c, Negative Nominal Interest Rates: Three Ways to Overcome the Zero Lower Bound. NBER Working Paper No. 15118.

Davies, Stephen, 2004, "Comment on Buiter and Panigirtzoglou," mimeo, Research Institute for Economics and Business Administration, Kobe University, May.

Eisler, Robert, 1932, Stable Money: The Remedy for the Economic World Crisis: A Programme of Financial Reconstruction for the International Conference 1933; With A Preface by Vincent C. Vickers. London: The Search Publishing Co. 
Goodfriend, Marvin, 2000, "Overcoming the Zero Bound on Interest Rate Policy," in: Journal of Money, Credit, and Banking, Vol. 32(4)/2000, S. 1007-1035.

Gorodnichenko, Yuriy, Johannes Wieland, and Olivier Coibion, 2012, “The Optimal Inflation Rate in New Keynesian Models: Should Central Banks Raise Their Inflation Targets in Light of the Zero Lower Bound?," 2012 Meeting Papers 70, Society for Economic Dynamics.

Graham, Liam, and Dennis Snower, 2011, "Discounting and Positive Optimal Inflation" CESifo Working Paper \#3464. Available at http://papers.ssrn.com/sol3/papers.cfm?abstract_id=1855897.

Jensen, Carina, and Morten Spange, 2015, "Interest Rate Pass-Through and the Demand for Cash at Negative Interest Rates," Danmarks Nationalbank Monetary Review $2^{\text {nd }}$ Quarter 2015.

Kaminska, I., 2009, Negative Interest in Cash, or Goodbye Banknotes. Ftalphaville.ft.com, May 20, 2009.

— 2013, A Digital Solution for the Repo Squeeze? Ftalphaville.ft.com, April 15, 2013.

—

Kimball, Christian, and Miles Kimball, 2015, "However Low Interest Rates Might Go, The IRS Will Never Act Like A Bank," Quartz, April 15, 2015,

http://qz.com/383737/however-low-interest-rates-might-go-the-irs-will-never-actlike-a-bank/.

_ 1995, "The Quantitative Analytics of the Basic Neomonetarist Model," Journal of Money, Credit and Banking 27(4) November, pp. 1241-1277.

__ 2013, "Larry Summers Just Confirmed That He Is Still A Heavyweight on Economic Policy," Quartz, November 13, 2013, http://qz.com/147861/larrysummers-just-confirmed-that-the-world-still-has-to-pay-attention-to-him/.

— 2014, "On the Great Recession," blog post http://blog.supplysideliberal.com/post/77682933130/on-the-great-recession.

Mankiw, N. Gregory, 2009, "It May Be Time for the Fed to Go Negative," in New York Times, April 18.

Rogoff, Kenneth, 2014, "Costs and Benefits to Phasing Out Paper Currency," NBER Chapters, in: NBER Macroeconomics Annual 2014, Volume 29 National Bureau of Economic Research, Inc. 


\section{APPendix I. Potential Steps in the Transition From PAPER STANDARd TO EleCtronic Money}

An implementation of the transition from paper standard to electronic money could take the following steps:

1. Announce technical feasibility of eliminating the zero lower bound.

2. Strengthen macro-prudential regulation by raising equity requirements substantially above those prescribed by Basel III.

3. Ask banks and other financial firms to make contingency plans for negative interest rates.

4. Develop accounting standards for negative interest rates that take electronic money as the unit of account, and give to paper money the value of its worth in the market relative to electronic money.

5. Ask government agencies to prepare contingency plans for negative interest rates and non-par valuation of paper money.

6. Make it clear no one has the right to pay off large debts to the government in contexts where transactions are now routinely conducted with bank money.

7. Establish by law that debtors do not have the right to pay off large debts with paper currency at par when the market value of paper currency is below par.

8. Formally make money in central-bank certified bank accounts legal tender.

9. Announce the intent to introduce an electronic money system.

10. Lower the central bank's interest rate on reserves to zero or slightly below zero.

11. Lower the central bank's target interest rate, interest rate on reserves, and the central bank's lending rate substantially below zero.

12. If there is any sign of large increases in paper currency withdrawal, institute a time-varying deposit charge (levied on net deposits) when banks deposit paper currency with the central bank in exchange for reserves.

13. Discount vault cash applied to reserve requirements by the factor of (1-deposit charge).

14. Implement the accounting standards appropriate for negative interest rates and non-par valuation of paper currency.

15. Require payment of taxes and other substantial debts to the government in electronic form. 
16. Implement the contingency plans for government agencies.

17. Ask all firms to post prices in terms of electronic money.

18. Make it clear that firms are allowed to specify in contracts (including loan contracts) and in retail sale the terms under which they will accept paper currency. 